\title{
Toplumsal Sorunlardan Bireyin Dünyasına Zeki Demirkubuz Sineması'
}

\author{
Mehmet Yilmaz ${ }^{2}$ \\ Elçin Adıgüzel ${ }^{3}$
}

\begin{abstract}
Öz
Bir toplumun her alanında yaşanan değişim ve dönüşümler sinemada karşılığını bulmaktadır. Türk Sineması için de aynı durum geçerli olup son yirmi yılda dünya üzerinde dramatik bir seyir izleyen toplumsal, kültürel, ekonomik ve siyasal olmak üzere pek çok alanda gerçekleşen değişim ve dönüşümler sinemayı doğrudan etkilemiştir. İlk filmi C Blok ile 1999'dan beri topluma ayna tutan Zeki Demirkubuz, filmlerinde konu edindiği toplumsal olaylar ve karakterleri ile anılan gelişmelere tanıklık etmektedir.
\end{abstract}

Yeni Türk Sinemasının başlıca isimlerinden Zeki Demirkubuz'un filmlerinde toplumsal gerçekçi bir çerçevede ele alınan toplumsal sorunların şekillendirdiği son derece derinlikli bireysel dünyalar dikkat çekmektedir. Söz konusu dünyalar ve bunlardan topluma yapılan geri dönüşler anlatım üslubu ile incelemeye değerdir. Bu çerçevede yönetmenin C Blok (1994), Masumiyet (1997), Üçüncü Sayfa (1999), Yazgı (2001), İtiraf (2001), Bekleme Odası (2003), Kader (2006), Kıskanmak (2009), Yeraltı (2012) ve Bulantı (2015) olmak üzere 10 filmi kronolojik sırası ile tematik film çözümlemesi yönteminden yararlanılarak analiz edilmiş ve filmlerin toplum-birey ekseninde kurduğu bağ betimlenmeye çalışılmıştır.

Yönetmenin filmleri hakkında genel bir fikir verme hedefinin yanı sıra, Demirkubuz filmlerine konu olan erkek ve kadın yaşantıları, toplumsal gerçekçilik çerçevesinde karşılık bulan sorunların çıktısı olarak ayrıntılı biçimde irdelenmektedir. Keza toplumdaki gerçeklik ile Demirkubuz filmlerinin dramatik uzayı arasında bir bağ kurulmasına odaklanılarak konuya ilişkin gelecek çalışmalara yeni bir boyut kazandırılmak istenmektedir.

Anahtar Kelimeler: Zeki Demirkubuz Sineması, Toplumsal Gerçekçilik, Bireysel Dünyalar, Sinema, Sanat

\footnotetext{
1 Bu makale Ordu Üniversitesi Bilimsel Araștırma Projeleri Koordinasyon Birimince desteklenen "Toplumsal Gerçekçilik Akımı Perspektifinden Zeki Demirkubuz Sineması” adlı ve TS-1602 proje numaralı yüksek lisans tez projesi ve tezinden üretilmiştir.

2 Doç. Dr. Ordu Üniversitesi Güzel Sanatlar Fakültesi Sinema-TV Bölüm Başkanı, email:mehmet.yilmaz.dr@ gmail.com

3 Ordu Üniversitesi Sosyal Bilimler Enstitüsü Sinema ve Televizyon Bölümü Yüksek Lisans Mezunu, email: elcin.adgzl@gmail.com
} 


\title{
From Social Problems To Individual's World Of Zeki Demirkubuz's Cinema
}

\begin{abstract}
The changes and transformations occurred in every aspect of a society are found in the cinema. The same is true for Turkish Cinema, the changes and transformations that took place in many fields such as social, cultural, economic and political, which followed a dramatic course worldwide within the last two decades, directly had an impact on the cinema. Zeki Demirkubuz, who has reflected society since 1999 starting with his very first film $\mathrm{C}$ Block, testifies to the mentioned developments with social events and characters in his films.

Zeki Demirkubuz, one of the prominent names of the new Turkish Cinema, draws attentions with the individuals' worlds and their responds which were affected from social problems reflected within a social realistic frame in his films. These worlds and their feedbacks on society are worth reviewing in an expressionist way. Accordingly, 10 films of the director, namely C Blok (1994), Masumiyet (1997), Üçüncü Sayfa (1999), Yazgı (2001), İtiraf (2001), Bekleme Odası (2003), Kader (2006), Kıskanmak (2009), Yeraltı (2012) and Bulantı (2015) were analysed chronologically using the thematic film analysis method to describe the bond that the films established with society and the individual.

Besides the aim of giving a general idea about the director's films, the male and female experiences which are the subject of Demirkubuz films are examined in detail in the context of social realism. It is also aimed to give a new dimension to future work related to the subject by focusing on the connection between individualistic world which are shaped by social problems and the dramatic space of Demirkubuz films.
\end{abstract}

Keywords: Zeki Demirkubuz's Cinema, Social Realism, Individual Worlds, Cinema, Art 


\section{Giriș}

$\mathrm{S}$ inemada gerçek ve gerçekçilik kavramları, konuya yaklaşan kişinin hayata bakış açısı ve içinde bulunduğu toplumsal sınıfın durumuna göre farklılık göstermektedir. Sinema alanında 'gerçeklik' kavramıyla ilgili arayışlar ve "nasıl bir sinema" tartışmaları gerçekçilik akımına kadar uzanmıştır. Bu anlayış farklı dönemlerde, farklı eserler ile karşımıza çıkmışıı. Toplumsal gerçekçi anlayışın en önemli rolü ise toplumsal sorunlara karşı betimleyici bir pencere açabilmesidir. Toplumsal gerçekçilik çerçevesinde kabul edilen sorunlar kaçınılmaz biçimde eser sahibinin nesnel yaklaşımı ile sinemasal anlatı konusu olmuştur.

Sinemanın gerçeklik ile olan bağını irdeleyen geçmiş çalışmalar incelendiğinde sinemada iki farklı gerçeklikten bahsedildiği dikkat çekmektedir. Bunlardan birincisi gerçeklik illüzyonunu gizlemek biçiminde bir ideolojik işlev üstlenen kesintisiz gerçekliktir. Diğeri ise alıcıyı illüzyona olanak tanımayan bir tarzda kullanmaya çalışıp gerçekliğin asıl gayesini gerçeğin bir, hatta birkaç okumasını aktarma alanındaki yetisi olarak değerlendiren estetik bir gerçekliktir (Hayward, 2012:178). Sinemada gerçekçiliği sorun kabul eden yönetmen ve teorisyenler olarak Dziga Vertov, John Grierson, Robert Flaherty, Vittorio de Sica, Paul Rotha ve André Bazin sayılabilir (Coşkun, 2003:152-153). Anılan isimlerden Bazin için kavram, fiziksel ya da görünür gerçeklikten daha geniş bir anlam ifade etmekte; fiziksel gerçekliğin arka planında yer alan "insanın gerçekliği"ne vurguda bulunurken sinemanın gayesinin daha geniş anlamıyla "gerçekliği" alımlayıcısına aktarmak olduğu inancını taşımaktadır (Kibaroğlu, 2015: 60).

Gerçeklikolgusunun toplumsal boyuta taşınması ise Lukacs'ın tespitlerinde açıklamasını bulmaktadır. Toplumsal gerçekçilik olgusunu birey-toplum-tarih ekseninde irdeleyen önemli düşün insanlarından Georg Lukacs'ın karşılaştırması ile kavramın içi; natüralist metinlere egemen olan gereksiz detaylarla dolu bir fotoğraf ya da geç modern anlayış ile örülü eserlerdeki gibi bireyi psikopatolojik yalnızlık duygularına hapseden, onu tarih dışı, toplumdışı bir kavrayışla ele alan bir hayat anlayışı ile doldurulmamalıdır (Lukacs, 2000:105). "Toplumsal Gerçekçi” bir eser toplumu kuran güçleri tanımalı, toplumsal hayatın akışı içinde gerçekçi bir tutumla yarattığı kahraman ve karakterleri aracılığıyla kendi anlatı evrenini kurmalı, bunu somut kişi ve olaylarla, marazi psikolojik unsurlara saplanmaksızın, gerçekçi bir tutum içinde yapmalıdır (Çolak, 2011: 109).

Zeki Demirkubuz'un filmlerinde toplumsal gerçekçi bir kavrayış ile çizilen toplumsal meselelerin büyük ölçüde şekillendirdiği bireysel dünyaların topluma geribildirimleri konusu önemli bir yere sahiptir. Yönetmen evrensel problemlerden yola çıkarak; toplumsal gerçekçi bakış çerçevesinde yer alan sorunların bireye "dayatmaları" üzerinden bireysel dünyalara girmektedir. Toplumca onaylanan karakterin karanlık yanı ile yüzleşmek zorunda kalınması, toplumsal statü ve gücün aşk adına terkedilmesi, bahtsızlık, kurban olma ve benzeri konular yönetmenin filmlerinde toplumsal sorunlar karşısında bireylerin dünyalarındaki dönüşümlerin toplumsal dışavurumları olarak işlenmektedir.

"Kadınlık" ve "erkeklik" üzerine yönetmenin geliştirdiği savların bir özeti gibi okunabilecek olan filmlere ayrıntılı olarak bakmak, özellikle 1990 sonrası ve 2000'li 
yılların Türk sanat sineması hakkında fikir vermesi bakımından önemli olmaktadır. Keza toplumdaki gerçeklik ile Demirkubuz filmlerinin dramatik uzayı arasında bir bağ kurulmasına odaklanılması da konu hakkında gerçekleştirilen diğer çalışmalara yeni bir boyut kazandırmaktadır.

Yönetmen toplumsal sürecin birey üzerindeki etkisi ve buna bağlı olarak yaşadıkları duygu değişimi, geliştirdikleri tepki ve seçtikleri yaşam biçimlerini ele almaktadır. Geleneksel anlatının dışında bir yol izleyerek bireysel hikâyeler üzerinden toplumsal hayata bir bakış açısı sunmaktadır. Toplumsal gerçekçilik temasını, filmlerinde önemli ölçüde kadın-erkek figürleri üzerinde geliştirmekte ve genellikle de kadının aldatmasını ele alarak, aldatılan erkeğin trajedisini, toplumun farklı bir gerçeği olarak sergilemektedir.

Demirkubuz, filmlerinde bireysel hikâyeler üzerinden, toplumsal yapıya eleştiride bulunmuş ve toplumun birey üzerindeki etkisine vurgu yapmıştır. Bireyin yaşanan toplumsal olaylara, değişimlere karşı geliştirdiği tepkiler ve sergilediği davranışlar yönetmenin sinemasında belli temalar ile sunulmaktadır. Bu anlamda Demirkubuz seçtiği temalar ve temalara getirdiği sinemasal anlatım üslubu ile "sineması" olan bir yazar-yönetmendir. Filmlerinin senaryosunu kendi yazan yönetmen Astruc'un tabiri ile kamerasını adeta bir "kalem" gibi (Monaco, 2006:15) kullanmaktadır.

Çalışmada Zeki Demirkubuz'un 10 filmi (Çalışmanın gerçekleştirildiği zaman aralığı sonrasında vizyona girmesi nedeni ile yönetmenin son filmi Kor hariç) kronolojik sıra ile anılan eksen çerçevesinde tematik bir analize tabi tutulmakta ve yönetmenin filmlerindeki ortak anlatım özellikleri üzerine değerlendirmeler yapılarak birey toplum ilişki ve etkileşimi toplumsal gerçekçi bakış tarafından betimlenen sorunlar ekseninde sorgulanmak istenmektedir.

\section{Toplumsal Sorunlara Bir Pencere: Toplumsal Gerçekçi Bakıș ve Sinema}

Gerçekçiliğin çıkış amacı öncelikle sanatı klasik ve romantik akımların yapaylığından kurtarmak olduğu için, ilk önce estetik ve edebi bir kavram olarak 19. yüzyıl ortalarında Fransa'da ortaya çıktığı bilinmektedir. Başka bir ifadeyle gerçekçilik; üretimi gerçeğe sadık kalarak yapmayı amaçlayan ve gerçeğe en yakın anlamda ulaşmayı hedefleyen bir sanat akımıdır (Jacobson, 1990:25). Bu sebeple de gerçekçilik, bilinçli bir akım olarak 1853 'te Fransa'da ortaya çıkmıştır.

Toplumcu gerçekçilik, gerçeklikte var olan yaşamın gerçekçi yansıtııışı anlamına gelse de, gerçekliğin kendisinde de toplumcu dönüşüm için gerçek olanakların ve bu olanakları gerçekleştirecek güçlerin var olduğu bir zaman kesitinde, 20. yüzyılda mümkün olabilmiştir (Pospelov, 2014: 490).

Anılan yüzyılın en önemli kavramı ve "sorunu" şüphesiz ki modernleşmedir. Modernleşmenin belirleyicilerinden olan ve toplumsal sınıf, siyaset ve iktidar arasındaki ilişkilerin kavranarak anlam bulabileceği 'kent işleyişi', bugün dünyanın her yerinde tüm insanlar tarafından deneyimlenen "ortak bir sorun" olarak belirmektedir. Dolayısıyla kavram, altyapısını sağlayan; kentleşme, sanayileşme, pazar, endüstrileşme, 
demokratikleşme ve belki de en önemlisi "özgürlük ve birey hakları" duygularının tam olarak yaşanıp yaşanmadığına dair oluşan; ancak bireylerin farkında bile olmadığı 'ortak bir sorun'dur (Gürkan, 2013:223). Böylesi bir motivasyon ile şekillenen toplumsal yapının sanat alanında karşılık bulmaması olanaksızdır. Söz konusu koşullar baskın biçimde gerçekçi bir bakış ile sanat alanına taşınırken gerçekçilik, çöken kapitalizmi ve onun çürüyen kültürünü yansıtmak değildir sadece; aynı zamanda yeni bir toplumu ve yeni kültürü yaratabilecek sınıfın doğuşunu yansıtmaktadır. Toplumcu gerçekçilik şu anki gerçekliği bilmek değil, bunun nereye gittiğini bilmektir (Moran, 2000: 54).

Bir sanat olarak sinema da toplumsal gelişmelerinden büyük ölçüde etkilenmekte, yönetmenler içinde yaşadıkları toplumda tanıklık ettikleri değişim ve dönüşümleri kendine has üslupları ile anlatmaktadır. Toplumsal gerçekçi bakış ise toplumsal sorunlarını saptanması ve işlenmesinde önemli bir menfez sağlamaktadır.

Türk Sineması açısından da sanatın gelişim seyri izlendiğinde Türkiye'de 1960 hareketi sonrasında yoğunlukla toplumsal sorunlara eğilen filmler çekildiği görülmekte 1960 Hareketi sonrasında perdeye yansıyan ilk fikri hareketin de "toplumsal gerçekçilik" (Uçakan, 1977:11) olduğu anlaşılmaktadır.

Türk Sinemasında toplumsal gerçekçilik olgusunu değerlendirmek bakımından Halit Refiğ'in Ulusal Sinema Kavgası'ndaki "Yeni anayasa ve Toplumsal Gerçekçilik" adlı bölümü önemli bir rehber niteliğindedir. Refiğ'in saptaması ile 14'lerin tasfiyesi olayı, 1961 Anayasası, yeni kurulan siyasi partiler ve seçimler toplumun çeşitli sorunlarına farklı perspektiflerden bakma olanağı tanımıştır. Ertesinde meydana getirdiği siyasi canlılık ile 27 Mayıs müdahalesi, sinemada "toplumcu gerçekçilik" olarak tanımlanan toplumun yapısı ve bu yapı içinde çeşitli katlardan insanların ilişkilerini anlatmaya çalışan bir akımın doğmasını sağlamıştır (Refiğ, 2013: 29-30). Askeri müdahale, bir çok sahada olduğu gibi sinema için de bir iyimserlik rüzgarı estirmiş, Demokrat Parti iktidarının başta sansür olmak üzere her türlü baskısının artık ortadan kalkacağı kanaati, Türk Sinemasının sansür endişesinden azade bir biçimde toplumsal konulara yönelme isteğini artırmıştır (Özön, 1966:11). Türk Sineması'ndaki "toplumsal gerçekçilik" akımı bir çeşit batılılaşma ve aydınlar hareketi olarak görülmekte olup en tipik temsilcileri Metin Erksan, Halit Refiğ, Vedat Türkali (özellikle senaryo yazarı olduğu ve Ertem Göreç'in yönettiği filmleri göz önünde bulundurulduğunda) olarak sıralanmaktadır (Refiğ, 2013: 41).

Türk Sineması'nın 1960 sonrası ilk beş yıllık dönem "toplumsal gerçekçilik" akımının egemenliğinde geçmiştir. Dünyada Gorki, Steinbeck gibi yazarların romanlarının ana temaları üzerine kurulu filmlerle hayata geçirilmiş toplumcu gerçekçilik Türk Sineması'nda 60'larda rağbet bulabilecektir. Metin Erksan'ın "Gecelerin Ötesi", Memduh Ün'ün "Kırık Çanaklar”ı, Atıf Yılmaz'ın Suçlu'su bu akım doğrultusunda gerçekleştirilen filmlerdir (Scognamillo,1988:13). Bu dönemde Türkali ve Göreç ikilisinin "Otobüs Yolcuları" şematik açıdan da olsa kendi çapında "sosyal realizm" dersleri vermektedir. Senaryosu ve yönetmenliği Ömer Lütfü Akad'a ait 1955 yapımı "Beyaz Mendil"den beri dört başı mamur yeni bir film bulamayan izleyici, Metin Erksan'ın "Yılanların Öcü" (Fakir Baykurt'un aynı adlı romanından uyarlanan, 1962 yapımı) ile sarsıımıştır (Hakan, 2014:227). "Yılanların Öcü”nü farklı kılan köy konusuna getirdiği sade ve toplumsal gerçekçi bakıştır. "Yılanların Öcü" ve Halit Refiğ'in 1962 
yapımı "Şehirdeki Yabancı"sı ile Türk Sineması'nda "toplumsal gerçekçilik" akımından söz edilmeye başlanmıştır (Refiğ, 2013: 34). Ne var ki Refiğ'in tabiri ile 1960-1965 yılları arasında Türk Sineması için toplumsal gerçekçilik akımı 27 Mayıs hareketi gibi halka inememiş olup "Otobüs Yolcuları", "Acı Hayat” ve "Gurbet Kuşları" dışında halk açısından popüler olan toplumsal gerçekçilik filmi neredeyse yok gibidir (2013: 42).

Türk Sineması'nda toplumsal gerçekçilik 1964 yapımı "Karanlıkta Uyananlar" ile bir kez daha gündeme gelir. Filmin farklılığı toplumcu tutumundan kaynaklanmakta, bu film ile emekçinin yaşantısı, gerçek ve yaşamsal meseleleri bir uzlaşıya gidilmeksizin, pembe gerçeklik ve gereksiz duygusal güldürüye kapılmadan sunulmaktadır (Scognamillo'dan akt. Hakan, 2014:265). İkinci Antalya Film Festivali'nde tartışmaların odağına yerleşerek büyük ses getiren film ile 10 Ekim 1965 seçimlerinin yaklaştığı günlerde en güçlü parlayışını yapan "toplumsal gerçekçilik" akımı, kendisini doğuran 27 Mayıs olayının son günlerini yaşaması gibi sönmeye başlarken, yaygın gürültülerin kesilmesi akabinde "Karanlıkta Uyananlar" da unutuluşa terkedilir. "Yılanların Öcü"nde Irazca Ana'nın direnişi ile başlayan "toplumsal gerçekçilik" hareketi "Haremde Dört Kadın"da tıbbiyeli Jöntürk'ün, uğrunda mücadele ettiği insanlardan biri tarafından kalbine saplanan bıçak ile sona ermiş olur (Refiğ, 2013: 39).

Toplumsal Gerçekçi filmlerin çoğu, dönemin ideolojik yapısına paralel olarak, kent filmidir ve darbenin sosyal etkilerini en yoğun olarak hisseden şehir insanlarının hikâyelerini anlatır. Bu filmlerde "geleneksel burjuvazi" ve onun değer yargıları, mülkiyet duygusu, kar hırsı şiddetle eleştirilir. Devlet ve onun kolluk güçleri (polis, asker) genelde adaletten ve zayıftan yanadır (Daldal, 2005: 94-95).

Toplumsal Gerçekçi Türk Sineması akımına göre, sosyal problemlere yönelinmeli, hakları elinden alınan ya da suiistimal edilen emekçi kitlelerin sorunları, şehirleşme ve sanayileşmenin getirdiği sonuçlar incelenmeli, bunlara çözüm yolları araştırılmalıdır. Bu yönelimle, bütün dramatik kurgu, daha durgun, daha soğukkanlı, daha bilimsel bir özelliğe doğru gidilmiş ve ifadeler, aşırılıktan kurtularak, konular halkın sosyal hayatında birer yara haline gelen günlük sorunlardan seçilmiştir (Uçakan, 2010: 2426).

Tam da bu noktada Zeki Demirkubuz toplumsal sorunlar ve dönüşümlerden ziyadesi ile etkilenen bireyin dünyasına girmekte, toplumsal gerçekçi bir yaklaşım ile ele aldığı toplumsal meselelerin bireyi nasıl etkilediğinin yanı sıra bireyin topluma verdiği geri dönüşleri de irdelemektedir.

\section{Zeki Demirkubuz'un Sinemasında Esinlendiği Bașlıca Kaynaklar}

Demirkubuz, 1980'ler sonrasında Türk sinemasında görülen sıkışıklığın, yetersizliğin ve üstünkörülüğün ardından, hem anlatım, hem de biçim olarak Türk Sineması'nın yeniden canlandığı 90'lı yıllara damgasını vuran yönetmenlerin başında gelmektedir. "Geleneksel Yeşilçam tarzına 1990 sonrasında karşı durarak, kendi sinemasını oluşturmaya çalışan kuşak" (Pösteki, 2005: 14) içinde yer alan yönetmen, bireyin toplum ile mücadelesini, toplumda meydana gelen değişimlerin ve sınıf değişimlerinin bireylerin dünyaları üzerindeki etkisini anlattığı filmi C Blok ile sinema dünyasına giriş yapmıştır. Sinema kurallarının ve üretim sürecinin dışında kalmaya çalışan Demirkubuz, suç, 
vicdan, kötülük, iradesizlik, suçluluk, sadakat gibi temaları filmlerinde kullanmaktadır. Dostoyevski gibi kurtuluşun acıda ve kötülükte olduğuna inanır. Kötülük ve suç, vicdan getirmektedir. Karakterleri bir yönüyle kötü insanlardır (Pösteki, 2005: 107-108).

Zeki Demirkubuz'un sinemasındaki üslubü itibari ile hayata bakış açısı ve düşünce tarzı anlamında büyük ölçüde Dostoyevski'nin eserlerinden etkilendiği anlaşılmaktadır. Yönetmenin sinemasını besleyen diğer isimler ise, Albert Camus, Robert Bresson ve Andrey Tarkovski'dir.

Yönetmen, birçok söyleşisinde kötülük ve inançsızlık gibi konuların ilgisini çektiğinden, kendisini en fazla etkileyen sanatçının Rus yazar Dostoyevski olduğundan bahsetmektedir (Möller, 2003: 20-21). Yönetmen için Dostoyevski, insanın psikolojik yapısını çözümlemede adeta bir rehber gibidir.

Dostoyevski ile cezaevi yıllarında tanışan Demirkubuz, "Hayatı onunla öğrendim" diye de ifade eder. Hapisteyken okuduğu ve etkisinde kaldığı "Suç ve Ceza"nın devamını yazar. Sonrasında da filmlerinde hep Dostoyevski izlerine yer vermeye devam ederek, ünlü yazarın vurguladığı temaları sinemasına yansıtmaya çalışır (Birtek, 2014).

Dostoyevski büyük kenti, karanlık, renksiz bir yoksulluğun, mutsuzluğun ve perişanlığın egemen olduğu bir alan olarak görür ve onu ciddi, ağır ve koyu renklerle belirtir. Renksiz, ruhsuz, resmi binaları, bunaltıcı bir havası olan içki dükkânlarını, kendi deyimi ile 'tabut'lara benzeyen döşeli odaları anlatır. Buralarda, 'büyük kent' yaşamının en büyük kurbanları, yaşamlarını tüketmektedirler (Hauser, 2006:314). Bu perspektifte yönetmenin filmlerine bakılacak olursa benzer hayatları izleyiciye ilk filmi olan $\mathrm{C}$ Blok'tan bu yana anlattığı görülebilir. Yönetmen şehir hayatı içerisinde sıkışıp kalmış insanın en yalın halini anlatmaktadır.

Yönetmenin filmlerinde de bireyin içinde bulunduğu ruhsal durum ve yaşadığı gelgitler salt bir gerçeklik ile izleyiciye sunulmaktadır. Annesinin ölümüne tepkisiz kalan bir oğul, arkadaşlarının sahtekârlıklarından kaçmak için yalnızlığı seçen bir adam, her şeye rağmen sevdiği kadının peşinden gitmeyi seçmiş bir erkek gibi hikâyeler yalın bir biçimde izleyiciye sunulur.

Demirkubuz sinemasına bir başka ilham kaynağı ise Albert Camus ve varoluşçuluk felsefesidir. Camus'un filmlerindeki varoluşçu düşüncenin etkileri, sinemasının da temelini oluşturmaktadır.

Yönetmenin "Yazgı" ve "Itiraf" adlı filmlerinde etkisi hissedilen Camus da eserlerinde genellikle varoluşçu anlayıştan yola çıkmaktadır. Camus, bireyin yaradılışı nedeniyle büyük sorumluluk alması sonucunda girdiği bunalımdan kurtuluşu konu edindiği Yabancı'da bir hiç uğruna idama mahkûm edilen topluma ve kendine yabancılaşmış, annesinin ölümü dâhil her şeye kayıtsız yaklaşan Mersault'un öyküsünü anlatmaktadır (Camus, 1999: 11-15).

Zeki Demirkubuz sinemasında, edebiyattan esinlenmelerin yanı sıra, farklı iki yönetmenin de etkisi görülmektedir. Bunlardan biri Rus yönetmen Tarkovski, diğeri de Fransız yönetmen Bresson'dur. 
Tarkovski, filmlerinde derin felsefi sorular ortaya atarak, onların yanıtlarını arar. Onun anlayışında sanat, insan kaderini ve dünyayı mükemmele götürecek yolların arayışını anlatan bir dildir. Tarkovski'ye göre insan, evrenin yalnızca bir parçası değil, gerçekliğin varlık ve metafizik merkezidir. Tüm evren ve dünyadaki her şey, ancak insanla bağlantılı ve insanla etkileşim içinde olduğu zaman mantıklı, anlamlıdır ve belli bir düzeyde mükemmeldir. Bunun tersi de geçerlidir: Evrenin bütün eksiklikleri, her şeyi yok etme gücü ve kötülüğün kaynağı, aslında özgürlüğünü yanlış kullanan, diğer insanlardan ve evrenden kendini bencilce ayıran ve etrafındaki bütün varlığa hükmetmek isteyen insandır (Yergebekov, 2003: 21). Zeki Demirkubuz'un filmlerinde konu aldığı karakterler için yaptığı kişilik ve ruh çözümlemelerine Tarkovski filmlerinde de rastlamak mümkündür.

Yönetmen Demirkubuz'un ilham aldığı veya esinlendiği bir diğer yönetmen ise ünlü Fransız yönetmen Robert Bresson olmuştur. Sinema sektörünün Dostoyevski'si olarak nitelendirilen Bresson sinemasının temel özelliklerinden biri diyalogların, kamera hareketlerinin kısıtlı oluşudur. Yönetmen; erdem, masumiyet, suç, intihar, temalarını hemen hemen her filminde işlemiştir. Oyuncu seçimlerinde profesyonel olmayan yüzleri tercih etmiştir (Derindüşünce, 2009). Yönetmenin "Üçüncü Sayfa"sında, neredeyse kamera hareketi yoktur ve filmin genelinde doğal ışık kullanılmıştır. Bu kullanımda da, Bresson etkisi açıkça fark edilmektedir.

\subsection{Demirkubuz Sinemasının Kodları}

Bir yönetmenin sinemasından söz etmenin ölçütlerinden en önemlisi anılan yönetmenin tüm filmlerinde ortak üslup özelliklerinin bulunmasıdır. Demirkubuz filmlerinde; tema, olaylar dizisi ve karakterler üzerinde ortak niteliklerin varlığı dikkat çekmektedir. Bu unsurlar yönetmenin sinemasının adeta kodları olmaktadır.

\subsubsection{Yönetmenin temaları}

Yönetmen, bazı filmlerinde hayatın bir köşesine itilmiş, gecekondu bölgelerinde veya izbe olarak adlandırabileceğimiz otel odalarında yaşayan insanları ele alırken bazı filmlerinde ise son derece steril koşullarda bir mesleğe ve yaşam koşullarına sahip olan bireyleri anlatmaktadır.

Filmlerinde ele aldığı karakterler; içinde bulundukları sınıfsal durum, fiziksel koşullar ya da duygusal açıdan büyük bir karmaşıklık ve kıstırılmışlık duygusu içerisindedir. Bu kişilerin yaşamlarını anlatırken Demirkubuz, en çok yalnızlık, sessizlik ve trajik sonlar ile farklı kadınların yaşantılarını tema olarak kullanmayı tercih etmektedir.

\subsubsection{Yalnızlık}

Zeki Demirkubuz, filmlerinde aşk, suçluluk, kıskançlık, güzellik-çirkinlik, ölüm, inanç, cinsellik ve ikili ilişkiler, yabancılaşma gibi temaları işlemektedir. Yönetmenin filmlerinde en çok göze çarpan tema ise yalnızlık olmuştur. İnsanların yaşadıkları hayal kırıklıkları, çektikleri acılar, onları yalnızlığa sürüklemekte, sonrasında da derin bir bunalıma itmektedir. 
"C Blok"ta Tülay ve çevresindekilerin hayatları, mahalle olgusunda siteleşmeye geçilmesi ile birlikte büyük bloklar içinde yaşayan insanların hissettikleri yalnızlık duygusunu temsil eden karakterlerden biridir. Filmin ana karakteri Tülay'ın ISSIz yerlerde arabasıyla dolaşması, kendisine sözle veya elle tacizde bulunan erkeklerle beraber olmayı düşünmesi, onun yalnızlığından kaynaklanmaktadır. Filmde müzik kullanımının minimalize edilmiş olması, şehre dair araba, televizyon, ayak sesleri vb. seslerin kullanılması izleyiciyi modern dünyanın yalnızlığı ile yüzleştirmektedir. Yazgı'da ise, varoluşsal yalnızlığı ele alan yönetmen, toplum eleştirisini karakterlerin üzerinden yapmayı tercih etmekte, kendi hayatlarına yapılan müdahalelerde bile seyreden, tepkisiz ve yalnız bir görünüm sergilemektedirler. Yine "İtiraf"da da yalnızıık baskın temadır.

\subsubsection{Sessizlik}

Demirkubuz'un "C Blok", "Masumiyet”, "Üçüncü Sayfa" ve "İtiraf” olmak üzere dört filminin en ilginç noktalarından biri, kadın karakterlerin, erkek karakterler tarafından doğrudan kadın cinselliğine dair itiraf edilmeye zorlanması meselesidir. Bu dört filmde de bu çabanın sonuç vermemesi, kadınların ya suskunlukla, ya da öfkelenip bağırarak ve karşı tarafı susturarak kendilerinden isteneni vermemesi kayda değerdir. "Kadın karakterlerin ilişkide oldukları erkekler tarafından hesap vermeye zorlandıkları hiçbir durumda hesap vermemeleri erkeğin zaten kurulmamış olan otoritesine boyun eğmediklerine işaret etmektedir." (Koç, 2004:189). Ancak filmlerde kadının bu tavrı kadını güçlendirmeye yetmemekte dahası kadın maruz kaldığı şiddet ile ağır bedeller ödemektedir. Erkeklerde ise yıkılan evlilikleri veya sona eren ilişkileri karşısında psikolojik olarak yaşanan çöküntü, sadece kapalı kapılar arkasında yaşananlardan ibarettir. Erkek karakterlerin maddi dünyaları kadınların aksine ilişkilerinden bağımsız bir tablo çizmektedir.

$\mathrm{Bu}$ tema "Masumiyet"te çok belirgindir. Filmin ana karakterlerinden Hasan, eve geldiğinde konuşmayan kadın için, "Çocuğu da kendine benzetti. Biri televizyonun karşısına geçiyor. Diğeri de odaya. Ses yok, seda yok. Ne yaptım ben ona. Boynuzlanan ben. Onuru kırılan ben." diyerek, sessizlik-tepkisizlik vurgusu yapmak istemiştir.

Demirkubuz filmlerinde müziğe çok az verilmesi, olay yerinin kendi sesinin verilmesi de, aslında sessizliğe yapılan bir diğer vurgudur.

\subsubsection{Trajik Erkek Yașantıları}

Demirkubuz filmlerinde trajedinin merkezinde erkekler yer almaktadır. Filmlerdeki erkekler temelde iyidir, ama edilgen, iradesiz ve cesaretsizdir. Otoriter değillerdir.

Başlarına gelen olaydan sonra hayal kırıklığına ve yıkıma uğrarlar. Genellikle bu kötü olayların nedeni de kadındır. Kadınlar güçlü ve direnen karakterlerden onurlu ama zavallı karakterlere doğru salınırlar (Öztürk, 2006: 90).

Zeki Demirkubuz'un filmlerinin bazılarında erkek karakterler kimi zaman içlerinde bulundukları durumu aşacak gibi bir izlenim verse de sonuç olarak başladıkları noktaya geri dönerler ve bu durum işlenen hikâyeyi daha trajik bir noktaya taşır. 


\subsection{5. Ön Plana Çıkarılmıș Kadınlık}

Yönetmenin filmlerinde kadınlar, sıradan görünen ancak toplumun çok alışkın olmadığı fahişe ya da eşlerini aldatan evli kadınlar olarak sıra dışı tiplerdir. Yönetmen, çektiği filmlerin çoğunda kadın figürünü, boyun eğmeyen, aşkının peşinden giden, kocalarını aldatabilen ve topluma hâkim olan ahlak değerlerinin dışında bir noktada konumlandırmıştır. Demirkubuz'un filmlerinde ele aldığı kadın karakterler, erkekler karşısında meslekleri ya da başarılarıyla değil, cinsellikleriyle bildiklerini okuyan, erkekleri bu şekilde güçsüzleştiren bir görev üstlenmişlerdir.

Demirkubuz filmlerinde kadın, erkeğin güçsüz olmasına sebep olduğu, onu aldattığı ya da hayal kırıklığına uğrattığı için ön plana çıkmaktadır. Zaman zaman erkek şiddetine de maruz kalan kadınlar, onlara karşı koyamamakta, fakat bir süre sonra erkekleri terk ederek erkeğin statükosuna tehdit oluşturmaktadır.

\subsubsection{Așk ve Aldatma}

Yönetmenin filmleri genellikle kadın-erkek ilişkileri temeline dayandığından, aşk da kaçınılmaz olarak filmlerinin ayrılmaz parçasıdır. Erkek karakterlere, genellikle olanaksız da olsa karşısındakiyle birlikte olma isteğini dile getirtmeyi tercih eden Demirkubuz, kadın karakterlerde ise arzuları için, sevdiklerini yıllarca beklemeyi göze alan bir figür sergilemeyi seçmektedir. Ancak burada, aşk anlamında, erkeklere toplumsal cinsiyet çerçevesinden farklı bir yol çizmiş, sevdiği kadınlar için intihar eden, bunalıma giren erkekleri daha çok ön plana çıkarmış ve tüm bunların suçlusunun kadınlar olduğunu ima etmiştir.

Aldatma ise, başlı başına yönetmenin üzerinde durduğu bir temadır ve genellikle de birçok filminde bunu işlemektedir. Yönetmen aşk ve aldatma durumunu anlatırken toplumsal cinsiyetçiliğe bir gönderme yaparak, erkeğin acı çekişi ve aldatılışı ile izleyiciyi yüzleştirmekte ve ataerkil bir yapıya sahip olan toplum için, erkeğin acısını gizlemek zorunda hissetmesine sebep olan toplumsal baskıya bir göndermede bulunmaktadır. $\mathrm{Bu}$ durum toplumun yaratmış olduğu baskıya rağmen yaşanan hayatlar ile izleyiciyi karşı karşıya getirmektedir.

\subsection{Demirkubuz Sineması'nın Karakterlerinin Genel Özellikleri}

Yönetmen filmlerinde genellikle benzer ruh haline ve yaşam şekline sahip bireylerin hayatını konu edinmektedir. Demirkubuz her ne kadar filmlerinde farklı hikâyeleri işlese de, seçtiği karakterler aynı dünyanın içerisinde yer alan karakterlerdir. Tüm karakterlerin zaafları da, güçlü yönleri de birbirine bu yönden benzemektedir. Aldatan kadınlar, bunalıma giren erkekler, suçluluk ve yalnızlık yaşayan karakter tipleri, filmlerini ortak özelliklerindendir.

\subsubsection{Sevilen veya nefret edilen karakterler}

Yönetmenin filmlerinde ana karakterler, genellikle ya sevilen ya da nefret edilen tiplemeleri oynamıştır. Filmlerinde karakter oyunculuğuna çok önem veren Demirkubuz, kahramanlarını çok ideal prototipler halinde ele almamış ve yüceltmemiştir. 


\subsubsection{Yoksul karakterler}

Demirkubuz filmlerinde, gecekondu veya varoş tabir edilen mahallelerin özelliğini taşıyan karakterler dikkat çekicidir. Keza kapıcı, hizmetçi pozisyonunda yoksul karakterler de yönetmenin filmlerinde sıklıkla yer almaktadır.

\subsubsection{Aldatan Kadın Karakterler}

Toplumun kabul ettiğinin aksine, erkeklerden çok kadınların aldattığına inanan ve bunu hayatın çok normal bir gerçeğiymiş gibi vermeye çalışan Demirkubuz, kadınları, arzuları için mücadele eden, hedeflerine ulaşana kadar yılmayan portreler olarak çizer. 'Aykırı' olarak nitelendirilebilecek bu kadın karakterler, gazinolarda şarkıcılık, fahişelik yaparak hayatlarını idame ettirirler veya evli oldukları halde kocalarını aldatırlar. Hayatlarındaki erkekler bunalıma girip intiharın eşiğine sürüklenirken bu kadınlar, birlikte oldukları erkekleri avuçlarının içine alıp hayatlarına kaldıkları yerden devam etmekte, deyim yerindeyse bildiklerini okumaktadırlar. Bu temsil biçimlerinden yola çıkarak Oktan ve Küçükalkan (2013), Demirkubuz filmlerinde kadınların adeta şeytani varlıklar olarak tasvir edildiklerini dile getirmektedirler.

\subsubsection{Trajik Erkek Karakterleri}

Demirkubuz filmlerinde erkekler genellikle güçlü ve iradesi olmayan, otoritesini konuşturamayan, güvenen ancak sonrasında hayal kırıklığı ve yıkıma uğrayan karakterlerdir. Filmlerinde genelde erkeklerin böyle olmasının sebebi, kadınlara dayandırılmaktadır. Cesaretli davranamadığı, bildiği doğruları savunamadığı için, erkeklere sürekli acı çeker.

\section{Toplum, Birey, Toplumsal Gerçeklik Ekseninde Zeki Demirkubuz Filmlerinin Analizi}

Yönetmenin 10 filminin kronolojik sıra ile toplum, birey ve toplumsal gerçeklik ekseni çerçevesinde tematik film analize tabi tutulduğu bu kısımda, yönetmenin filmlerindeki ortak anlatım özellikleri üzerine değerlendirmeler yapılarak Demirkubuz Sineması'nda birey toplum ilişki ve etkileşimi toplumsal gerçekçi bakış tarafından betimlenen sorunlar ekseninde sorgulanmak istenmektedir.

\subsection{Blok (1994)}

Film, C Blok'ta yaşayan "burjuva" bir çift olan Tülay ve Selim ile bu çifte hizmet eden hizmetçileri Aslı ve bloğun kapıcısı Halet arasında geçmektedir. Her ne kadar gözle görülür, belirgin bir sorunları olmasa da, evliliklerinde mutsuz olan Tülay ve Selim, birbirleri ile iletişim kurmakta zorlanmaktadır. Yaşadığı sorunlar ile baş etmekte zorlanan Tülay'ın davranışlarında hayatındaki sorunlar ve Halit ile olan birlikteliği arasında yaşadığı gelgitler nedeni ile değişikliler başlar ve Tülay kendi içerisinde bilinçsizce bir arayışa yönelir. 


\subsubsection{Blok'ta yukarıdakiler, așağıdakiler...}

C Blok yönetmenin 1994'de çektiği ilk uzun metrajlı filmidir. Yönetmen 1997'de gerçekleşen bir röportajında filmin değerlendirilmesi noktasında önemli ipuçları vermektedir. Yönetmenin ifadesi ile C Blok'un klasik anlamda bir hikâyesi neredeyse yoktur. Filmin metafizik bir yanı vardır. Durumlarla, anlarla ilgili sahnelerin olduğu bir filmdir. Bir hikâye olmadan, bu apartmanları, yolları birincil kahraman olarak seçerek bunların içine nesne olarak anlatmayı hedeflediği, nesneleşmiş kahramanları, kadını, diğer insanları anlatmıştır. C Blok'un yönetmen için en önemli yanı, hayatta var olan değişikliklerden çok, yeni bir dünya yaratmak isteyen güçlerin sınanmasıdır (Kıraç, 1997). Yönetmenin de belirttiği gibi, klasik bir hikâyesi olmayan C Blok, bir durum sinemasıdır.

Demirkubuz toplumsal gerçekçi bir bakış açısı ile toplum içerisinde yer alan sıradan, gündelik hayatta karşılaşılabilecek birey/lerin hikayesini anlatmaktadır. Anılan bakış açısına sahip diğer sanatçılar gibi toplumda var olan herhangi bir insanın gündelik hayatında yaşadığı problemler ve bunlra dair çözüm arayışı ortaya konulmaya çalışılır. Bu nedenle filmlerin temelinde toplumsal bir olay yer alır ve sebep-sonuç ilişkisi sorgulanır. Filmlerin gerilim noktaları, olağan dışılık temelinde ele alınmaz. Film kahramanı ve içerisinde yaşadığı sosyo-politik süreç birlikte işlenir. Toplumsal gerçekçi film çeken yönetmenlerde genellikle burjuvazi ve kapitalizm karşıtlığı mevcuttur. $\mathrm{Bu}$ tutum, ya dolaysız bir toplumsal eleştiri; ya da kapitalist toplumdaki bireyin yabancılaşması ve değerlerini kaybetmesinin hikâyesi olarak kendini göstermektedir.

Ana karakter Tülay'ın kocasıyla mutsuzluğunun nedenini başka bir erkeğin kollarında araması, hizmetçisi Aslı'nın yaşadığı rahatlığa özenmesi, Aslı'nın ise sınıf atlamaya özlem duyması, sonrasında hep mazbut bir erkek görünüm çizen Selim'in önce Tülay'a, ardından Ası'ya tecavüz etmesi, filmin kritik noktalarıdır. Filmde, çekilen dönemin siyasi atmosferi, sosyo-politik yapısı birebir yansımasa da, Demirkubuz'un kapitalizm eleştirisi iyiden iyiye hissedilmektedir.

Yönetmen C Blok'ta yüksek inşa edilmiş bloklar ve gri bir gökyüzünü kullanarak kuşatılmış ve kıstırılmış yaşamlara gönderme yapmaktadır. Demirkubuz, filmin görüntülerinde sıklıkla yer verdiği apartman görselleriyle modern mimarinin insanların hayatlarını hapishaneye dönüştürmesi sonucu aradıkları çıkışları ağırlıklı olarak işlemektedir.

Filmde yönetmenin ele aldığı karakterler kendilerine ve çevrelerine yabancılaşmış aynı zamanda içerisinde bulundukları hayatta kaybolmuş ve nesneleşmiş bir yaşam sürmektedir.

Bu filmde gözden kaçmaması gereken en önemli öğelerden biri, yan karakterlerin diyaloglarını sanki bir kâğıttan okuyor gibi duygu yoğunluğu ve bütünlüğünden uzak, soğuk bir şekilde yansıtmalarıdır. Her ne kadar dönemin popüler teması olan kent hayatındaki yalnızlık ve buhran işlenmiş olsa da, bunu izleyiciye aktarabilmesi bakımından bu tercih filme olumlu bir katkı sağlamaktadır.

Film içerisinde olayların büyük bir çoğunluğu Tülay'ın arkadaşı Fatoş'a yaptığı anlatımlar üzerinden aktarılmaktadır. Müzik kullanımının en aza indirilmesi, etraftaki 
gerçek seslerin kullanımı, gri tonlarının tercih edilmesinin nedeni modern dünyanın birey üzerindeki etkisine ve onları yalnızlaştırdığına işarettir. Filmde müzik ve dışavurumcu sahnelerin yoğun olarak kullanılmış olması popüler beğeniye hitap edebilmek açısından yönetmenin verdiği tavizlerdendir.

“C Blok"'ta kadın ve kadın üzerinden aktarılan sınıf çelişkisi dikkat çekicidir. İzleyici, filmin ana karakteri Tülay ile ilgili sınıf atladığı ve öncesinde "varoş" bir mahallede yaşadığı gerçeğini olaylar dizisisin ileri aşamasında anlar. Selim ile evliliği sayesinde sınıf atlayan Tülay bu beraberlikten mutsuzdur. Tülay, Selim ile çok fazla iletişim kurmayan, arabasıyla sık sık yolculuk yapıp gitme eylemi arkasına saklanarak kişisel arınmasını yaşamaya çalışan ve cinsel olarak aradığı doyuma ulaşamamış bir kadındır. Bu yüzden de, kendisine elle ya da sözle tacizde bulunan erkeklerle bile yakınlaşarak heyecan aramaktadır. Tülay, evindeki hizmetçiyi, kapıcısının oğluyla kendi yatak odasında yakalayınca, hayatını sorgulamaya ve sonrasında Halet'e ilgi duymaya başlar.

Diğer kadın karakter Aslı ise, Tülay'ın hizmetçisi olup, Tülay evde yokken kapıcının oğluyla birlikte olan, Halet ile buluşurken Tülay'ın kıyafetlerini giyerek "güzelleşen", bir bakıma Tülay'ın sahip olduklarını ele geçirmek isteyen ve Tülay'ın hayatına ve sınıfsal konumuna özenen bir kadın olarak sunulur. İki kadın arasında sınıf farkı da olsa, aslında Tülay, hizmetçisi Aslı'ya bakarken, evlenmeden önceki hayatını görür. C Blok’ta, yönetmen, kadınların tatminsiz, ne istediğini ve aradığını bilmeyen, bulundukları sınıftan memnun olmayan bireyler olarak gösterirken; erkeklerin içine düştüğü durumdan da kadınları sorumlu tutar.

Filmde toplum ve bireyin dünyasında cinsel şiddet olgusuna da yer verilmektedir. C Blok’ta erkeğin fantezi objesine indirgenen kadın, görünüşüyle de bu fanteziyi destekler niteliktedir. Aslı, Halet'e "Bak ve iste bu kadını", "Erkeksen yakala" diyerek kendisini seyirlik bir nesneye dönüştürmekte, bununla bir erkeğin bir kadını hangi şartlarda isteyebileceğini özetlemektedir. Çünkü bir erkeğin bir kadına öncelikle bakması gerekir. Kadın da burada, erkeğin ona bakması ve sonra da harekete geçmesi için, elinden geleni yapan cinsel bir nesne gibi algılanmaktadır.

Filmin ana erkek karakteri Selim filmin önemli bir bölümünde ahlaklı bir figür olarak, toplumsal değerlerle çelişen mutsuz, tatminsiz, gözü dışarıda, sadakatsiz kadın temsili Tülay'ın karşısında toplumca onaylanan bir "erkek" biçiminde sunulmaktadır. Filmin ilerleyen sahnelerinde Selim, karısının kendisine olan uzaklığının ve soğukluğunun sebebini sorar. "Kocana bir şey açıklaman gerekmiyor mu? Söyle, neler oluyor?" der ancak Tülay'dan bir cevap alamayınca, ona hafifçe vurur. Sonrasında da karısının sessizliğinden ve konuşmamasından bunalan Selim, öfkesini cinsel saldırı ve şiddet ile bastırmaya çalışır. Tecavüz sahnesi, Selim'in iyi tarafını anlatan sahnelerin üzerine verilmiş, yönetmen tarafından adeta "yumuşatılmıştı". Tecavüzden sonra Tülay, Halet'e giderek onunla birlikte olur.

C Blok finali itibariyle bitmiş duygusunu seyirciye vermez. Tülay'a ne oldu, Halet iyileşti mi? Aralarındaki ilişki devam etti mi? Bunların hiçbiri cevap bulmaz. Çünkü aynı hayattaki gibi öyküdeki insanlar da kendini tamamlamıştır. Ve film bu "tamamlanmamışıı" duygusuyla seyirciyi baş başa bırakmaktadır. 


\subsection{Masumiyet (1997)}

Çıkışsızlık-parçalanmışlık üzerine kurulu film Uğur, Bekir, Yusuf ve Çilem ekseninde yaşanan olayları konu edinmektedir. Uğur, güçlü ve sert bir karaktere sahip olan bir hayat kadınıdır. Bekir ise Uğur'a karşı "saplantıı" bir aşk beslemektedir. Yusuf hapishaneden yeni çıkmış, herhangi bir amaca sahip olmayan ve Bekir gibi Uğur'a aşık diğer figürdür. Çilem ise ve annesinin hamilelik sürecinde şiddete maruz kalması sebebi ile sağır ve dilsiz olarak doğmuştur. Filmde, pavyon şarkıcısı olan ve para karşılığı erkeklerle beraberlik yaşayan Uğur'un çaresiz aşkı ve ona duydukları aşk nedeniyle hayatları kararan Bekir ve Yusuf'un hikâyesi anlatılmaktadır.

\subsubsection{Sıradan insanlar, așırı duygular...}

Toplumsal gerçekçi bir bakışa sahip Demirkubuz filmlerinin tamamının arka planında mutlaka bir toplumsal mesele irdelenmektedir. Burada, arkadaşını öldürdüğü için katil olan, bu yüzden hapse giren, cezasını çektikten sonra hapishaneden çıkan ancak hayattan korkan bir adam olan Yusuf karakteri, toplumsal gerçekçiliğin farklı bir boyutunu sergilemektedir.

Toplumsal gerçekçi filmlerin en önemli özelliklerinden biri, kahramanların hepsinin hayatın içinde her an karşılaşabileceğimiz insan tiplemeleri olmalarıdır. Masumiyet'te de, üstün insan tiplemeleri yoktur. Masumiyet'teki ana karakterlerden Yusuf, Bekir ve Uğur, öyküleriyle, iyilikleri ve hatalarıyla, şiveleri ve tepkileriyle içinde bulunduğu sınıfsal niteliğin gerçekliğine uygun verilmeye çalışılan ve ayrıca filmdeki yeri, yakın ağırlıklarda olan, birden çok bulunan ana tiplemelerdir.

Üçüncü sınıf otel odaları, otobüs terminalleri, bodrum katında bir ev, gecekondu mahalleleri, taşra pavyonları gibi temalar, filmde yine hayattan verilen kesitler şeklindedir.

Yönetmen, tek plan ile Bekir'in hayatını izleyiciye aktardığı birkaç dakikalık sahnede alışılagelmiş kalıpların dışına çıkmıştır ki sahne Türk Sineması'nda en çok sözü edilen sahnelerden biri olmayı başarmıştır. Anılan anlatım biçimini yönetmenin diğer filmlerinde de görmek mümkündür.

Filmde, belirgin temalardan biri, dilsizliktir. Yusuf'un ablası da, Uğur'un çocuğu Çilem de dilsizdir ve ortak paydaları ikisinin de erkek şiddeti yüzünden dilsiz kalmış olmalarıdır. Filmdeki bu dilsizlik - sessizlik temasının kadınlar açısından bir direnme pratiği olup olamayacağı tartışmaya açık bir konudur. Dilsizlik temasını işleyen sahnelerde, gerek Yusuf'un ablasının dilsizliği, gerekse Uğur'un çocuğu Çilem'in dilsizliği, bir kabullenmişliği anlatmaktadır. Sürekli şiddet gördüğü anlaşılan Yusuf'un ablası, yaşadıkları karşısında tepkisiz kalmakta, boyun eğmektedir. Burada kadın, cezalandırılmakta, geçmişte yaptıklarının bedelini her gün tekrar tekrar ödemektedir. Çilem ise, annesinin ona hamileyken babası dövdüğü için dilsiz kalan küçük bir çocuktur ve çevresinde olup bitene tepki vermemektedir. Çilem'in sessizliği de dönüştürücü olmaktan ziyade, mevcut durumu olduğu gibi kabullenen bir his içermektedir. 
Masumiyet'te karakterlerin davranış ve tutumlarında, yansıttıkları duygularda aşırılık hâkimdir. Aşırı tutku, aşırı sessizlik, aşırı şiddet gibi...

Filmin çoğu sahnesi kapalı yerlerde geçer; dışarıda geçen sahnelerde ise güneş hemen hemen hiç görülmez. Filmin mekânlarında adeta bir kapatılmışlık, kuşatılmışlık duygusu hâkimdir.

Erkek karakterler sıkışmışlık duygularının sorumluluğunu hayatlarındaki kadınlara yüklemektedir. Kadın, suçlanan konumdadır. Enişte karakterinin karısını kemerle döverken söylediği; "Ne yaptım ulan, ne yaptım ben sana? Dilsiz o.. k..! Beni yok ettin ulan sen. Öldürdün lan beni. Mezara gömdün lan.” şeklinde bağırması, bunun bir göstergesidir. Yusuf'un ablası, neticede aile namusuna zarar verdiği görüşünün arkasına sığınılarak cezalandırılmış bir kadındır. Kadın figürü, evli olduğu adama hiçbir şekilde sevgi beslemeyişi ve kocası tarafından şiddete maruz kalmasına rağmen sessizliğini bozmaz; bu davranış aynı zamanda kendisine dayatılanlara karşı verilen bir tepkidir.

Bekir karakteri, sevdiği kadın Uğur'a olan tutkusunun sonu olmadığı için bunalıma girer ve bir gece Uğur'la olan tartışması sonucu intihar eder. Yönetmen, ana karakterlerden birini filmin ortasında öldürmüştür. Bu durum da, farklı bir aşırılık noktasıdır.

Filmde Uğur aykırı bir karakter olarak yansıtılmaktadır. Fettan, bildiğini okuyan, sivri dilli, ağzı bozuk, sevgilisine ulaşmak için fahişelik yapan biridir. Anne olmasına rağmen, şefkatli ve anaç olmadığı gibi, çocuğuna düşkün de değildir. Filmdeki bir diğer aşırılık da budur. Kadına, yaşadıkları olaylar karşısında fahişelik dışında bir kapının açık bırakıımamış olması sorunların temel kaynağıdır. Oysa kadının, hayatını devam ettirmek ve güçlü kalabilmek için, başka araçlara da intiyacı bulunmaktadır.

\section{3. Üçüncü Sayfa (1999)}

Demirkubuz, üçüncü filminde de bir öncekinde olduğu gibi kaybedenlerin dünyasını anlatmayı ve "çıkışsızlık" temasını işlemeyi sürdürmektedir. Olaylar dizisi, filmlerde figüran olarak çalışan İsa'nın mafyavari bir ortamdan elli dolar çalmakla suçlanması ile başlar. İsa eğer arayı bir gün içinde bulamazsa öldürülmekle tehdit edilir. İsa içine düştüğü çıkmazdan kurtulamayacağını düşünerek intihar etmeyi planlar ve kafasına silah dayar. Bu esnada ev sahibi kapıyı çalar ve kendisinden kira borcunu ödemesini ister, İsa o an içinde bulunduğu ruh halinin etkisi ile ev sahibini vurur ve olaylar gelişir.

\subsubsection{Ezilen kadının tek çıkıs yolu ezmek mi?}

Toplumsal gerçekçi bakış ile örülen filmlerde kahramanların hayatın içinden figürler olduğu görülmekte olup burada da hayatın içinden ve sıradan denilebilecek karakterler mevcuttur.

Filmin başlangıcında, ana karakterlerden biri olan Meryem, boynunda taşıdığı dini simge çerçevesinde ele alındığında merhameti taşıyan karakter olarak görülmektedir. İlerleyen sahnelerde, İsa'nın dövülmesine şahit olduğunda bu olaya engel olur ve 
İsa'nın borcunu ödeyerek onu kurtarır. Yönetmen Meryem'in televizyon ve gerçek dünya arasında sıkışıp kaldığını izleyiciye gösterir. Meryem yaşamak istediği ancak hiçbir şekilde ulaşamayacağını bildiği ve yaşamak zorunda olduğu hayat arasında sıkışmıştır. Buradaki ironi Meryemin ünlü bir şarkıcının adına atıfla çocuğuna verdiği Sibel üzerinden aktarılmaktadır.

Film boyunca üst katta yaşayanların bir şekilde alt katta yaşayanları sömürdüğü görülür. Apartmanın ev sahiplerine ayrılan iyi daireleri ve Meryem'in deyimiyle "ahır" gibi daireleri vardır. İsa ev sahibi tarafından hakarete; Meryem yine ev sahibinin cinsel istismarına uğrar, hatta onun metresi gibi olur ve kocası da ev sahibi aynı zamanda patronu olduğu için buna göz yumar.

Meryem için köyden uzakta, İstanbul'da yaşamak kocasından kurtulmaya dair bir umut demektir. Kocasını öldürmeyi, cesedi bir çukura atarak kaybetmeyi planlayan Meryem'e göre, "her gün bir sürü insanın öldürüldüğü koskoca İstanbul'da polis işini gücünü bırakıp onu mu bulacaktır". Tüm bu vurgular, gerçek hayattan, toplumsal sıkıntılardan, toplumda yaşanan gerginliğin, işlenen cinayetlerin, perde arkasını aralar niteliktedir ve toplumdan birebir izler taşımaktadır.

Üçüncü Sayfa ile Demirkubuz, ezilenlerin birbirlerini ezmek ve birbirlerine kıymak dışında başka çıkış yolu bulamadıkları karamsar bir tablo çizmektedir. Kadın bu filmde yine güçlü bir karakter değildir; hem ev sahibi, hem kocasıyla ilişkisi vardır, sonra da ölen ev sahibinin oğluyla evlenir. Bir anlamda, statü değiştirmek için, kadınlığını kullanarak, istediği erkeği elde etmiş, onunla evlenmiş ve olmak istediği yere gelmiştir. Kadının bu şekilde ele alınması, toplumdaki kadının gerçekten böyle mi olduğu sorusunu tartışmaya açmaktadır. Demirkubuz sinemasının bir klasiği haline gelmiş olan "mazlumluk" teması, "Üçüncü Sayfa"da da vardır. Yönetmen, burada, mazlumluk temasını İsa karakteri ile örtüştürmüş ve erkeklerin mazlumluğunun nedenini kadınlara bağlamıştır. Çalmadığı halde hırsız damgası yiyen, dövülen, borçlarını ödeyemediği için ev sahibi tarafından hakarete uğrayan, mafyadan kaçan İsa karakteri, acı da çektiği için 'mazlum'dur. İsa, hayatın zalimliği karsısında yenik düşmüş bir karakterdir. Sistemin en altındadır. Güçsüzdür. İntihara karar verir ancak onu bile yapamaz. Oyuncu seçiminde "acılara rağmen başaran bir insanı oynamak" istediğini söyler. Aslında olmak istediği kişilik budur fakat ne kadar çabalasa da olamamaktadır. Sevdiği kadın tarafından beklenmedik bir darbe alır ve hayatına intihar ederek son verir. İsa karakterinde, acı, çile, ıstırap, öfke ve hınç adeta iç içe geçmiştir. Bu yüzden mazlumdur. Zalim dünyadan hıncını ev sahibini öldürerek alır, sevgi intiyacını Meryem'le gidermeye çalışır ancak bunda başarılı olamaz. İsa'nın odasında asılı duran "Dört Yanım Cehennem" ve "Küskünüm" adlı filmlerin afişleri, İsa'nın yaşadığı acıyı, haksızlığı ve tehdit altına girdiğinde içindeki ezikliği dile getirmektedir.

Demirkubuz gelir düzeyi düşük olan insanlar arasında yaşanan en büyük sorunun kendi aralarında yarattıkları problemler olduğunu ifade eder. Bu insanlar her ne kadar sistem içerisinde mazlum olarak görülse de kendi aralarında birbirlerini ezmekte ve birbirlerine zarar vermektedirler.

Demirkubuz'un betimlemesi ile kadın tehlikeli bir varlıktır. Bu filmde de yönetmen, bir kadının ne kadar acımasız olduğunu göstermek istemiştir. Bu bağlamda kocasının 
tecavüzüne uğrayan, kocası tarafından dövülen ve ev sahibi erkek ile "istemeyerek de olsa” ilişkiye giren Meryem'in yaşadığı travma yeterince görünür kılınmamış; bunun yerine İsa'nın trajedisi ön plana çıkarılmıştır. Filmde İsa'nın eğitim düzeyine ilişkin bir bilgi verilmemesine rağmen, düzgün bir işi ve mesleği olmaması, kendisine iyi gelir getirecek bir meslek sahibi olmasını sağlayacak bir eğitim almadığını göstermektedir. Toplum tarafından erkekler için uygun görülen ve statü sahibi olmasını sağlayacak bir mesleği olmadığından İsa, sosyo-ekonomik olarak güçsüzdür. Bunun yanında, İsa'nın Meryem ile olan yakınlaşması onun bir aile sahibi olma, sahip çıkma ve koruma istemini ortaya koymaktadır. Öte yanan, kocasından dayak yiyen Meryem'in çığlıklarını duymasına rağmen, kapısına kadar gider fakat müdahale edemez. Çünkü ne fiziksel, ne de ruhsal olarak güçlü değildir; korkak ve ezilen bir kimliktir. Duygularını belli etmekte ve duygusal tepkilerini öfke, kızgınlık ve ağlamakla göstermektedir. Kötü mizaçlı olmayan İsa, Meryem'in kocasını öldürme teklifini istemeyerek de olsa kabul etmesine rağmen bir türlü gerçekleştiremez. Meryem "Erkek misin lan sen?" diyerek İsa'yı aşağılar ve erkekliğini sorgular. İsa, şiddete eğilimi olan bir erkek kimliği değil bilakis kendisine uygulanan şiddet karşısında bile karşılık veremez pasifliktedir. İsa, yaptığı ve yapacağı kötülükler yüzünden acı çekerken, Meryem kötü olmayı ve vicdan azabı duymamayı öğrenmiştir.

Gerçek hayatta figüranlık yapan, ama hayallerinde başrolü "ibrahim abi” gibi oynamak isteyen, sevgisini paylaşmak istediği kadından yoksun kalan İsa, kendini dayanılmaz bir boşluğun içinde bulur ve intihar eder. İsa, olmak istediği yerde olamamış; başarı ve sevgi ideallerine ulaşamamıştır. Filmde, İsa'nın hayatı daha fazla ele alındığı için, ister istemez, bir erkek gerçekliği ile karşı karşıya kalınmaktadır. Yara aldıkça mazlumlaşan, mazlumlaştıkça yara alan İsa, "istekli" ancak "iradesiz"dir.

\subsection{Yazgı (2001)}

Albert Camus'nun "Yabancı" adlı eserinden uyarlama izleri taşıyan filmdeki "Musa" karakteri, "Yabancı"daki Meursault karakterine benzerlikler göstermektedir. Film, gümrük memuru olarak çalışmakta olan Musa'nın hikâyesi üzerine kurulmuştur. Musa, genellikle birbirine zıt olan iki durum arasındaki farka tepki gösteremeyen birisidir. Öyle ki, annesinin ölümüne bile tepki vermez. Daha sonra çocuğun ve bir annenin katili olmak ile suçlandığında da bu duruma tepki göstermez. Öykü bu fark edememe ya da duyarsızlık ekseninde gelişir.

\subsubsection{Sınırları zorlayan kayıtsızlı̆ı ile Musa’ya katlan(ma)mak...}

Filmin ana karakteri olan Musa ahlaki normların dışındadır. Bu tarz bir karakter seçimi ile seyircide nefret ve sempatiyi aynı anda uyandıran bir kimlik üzerinde çözümleme yapmak hedeflenmektedir. Burada asıl sorulması gereken Musa'nın temsil ettiği karakterin ne olduğu ve bireyin toplumsal kurallarını yok sayarak var olup olamayacağıdır. Musa'nın içerisinde olduğu bu beklenmedik davranışlar ve hiçlik duygusu, bireyin toplum içerisinde var oluş çabası aynı zamanda toplumsal gerçekliğin de bir yansımasıdır.

Filmin ilk sahnelerinde annesi ile sıradan bir hayat yaşayan Musa, ilerleyen sahnelerde sergilediği tavırlar ile klasik bir kahraman olmaktan çıkar. Musa'nın annesinin ölümünü 
iki gün sonra fark etmesi ve bu ölümü fark ettikten sonra yaşadığı rahatlama duygusu, aslında Musa'nın üzülmediğini değil olaylar karşısında tepkisiz olduğunu göstermektedir ki bu tepkiler alışılagelmiş davranışların dışında olduğu için yadırganmaktadır. Demirkubuz, Musa karakteri ile toplumsal normların dışında bir figür yaratarak, bireyi kendisine dayatılan yüklerden kurtarmayı amaçlamaktadır. Musa'nın bu alışıımışın dışındaki davranışları bir karşı duruşu temsil etmez, bu tamamen bireysel bir tercihtir. Bu tavır sayesinde de toplumda açıklanmayan ya da bilinmeyen bir gerçeği su yüzüne taşımaktadır.

Musa ile savcı arasında geçen sahne ise filmin en dikkat çekici sahnesidir. Musa, Patronunun karısı ve çocuklarını öldürmek suçundan dört yıl hapis cezasına mahkûm edilir. Musa hiçbir tepki göstermezken, patronu yaşadığı vicdan azabına dayanamaz ve her şeyi itiraf eden bir mektup bırakarak intihar eder. Bu mektubun mahkemeye ulaşmasının ardından savcı Musa'ya masum olmasına rağmen bunca zaman neden sessiz kaldığını sorar, ancak Musa yine herhangi bir tepki göstermez. Savcı, Musa'ya inanç ve Tanrı ile ilgili sorular sorar ve böyle şeylere inanmadığı cevabını almasının ardından şaşırarak “Üzerinde düşünmediniz mi hiç?” der, Musa'dan "Benim için üzerine düşünülecek bir şey değil” cevabını alır. Bu diyalogdan da anlaşılabileceği üzere Musa için hiçbir şey anlam ifade etmemektedir.

Musa, annesinin ölümüne bile kayıtsız kalan bir karakterdir. Illgi duyduğu Sinem'in ise aslında cinsel yönüne karşı bir tutku beslemektedir ki bu tutku da geçicidir. Musa karakterinin tutkusunun altı, ara sıra Sinem'in bacaklarına bakması, bacaklarını okşaması, hapisteyken ziyaretine gelen Sinem'in gömlek düğmelerini açmasını istemesi biçiminde çizilmektedir. Musa için Sinem karakteri, "bacak" ve "göğüs"e indirgenmiştir.

Filmdeki diğer karakter olan Necati de, aynı kadına -Sinem'e- ilgi duyan ve onunla metres hayatı yaşarken, ona sahip olamamaktan yakınan bir figürdür. Necati'nin kadını cezalandırma şekli de ayrıca düşündürücüdür. Cinsel ilişki sırasında kadına küfretmeye başlayan ve onu yarı çıplak bir vaziyette kapının önüne atan Necati karakteri, bu yolla kadın üzerindeki hıncını almaya çalışmakta, erkekliğini ispatlama mücadelesine girmektedir.

Filmde, Musa karakteri karısının aldatmasına sözle veya eylemle herhangi bir tepki göstermediğinden devreye toplum girmiştir. Musa'nın cinayetten mi, aldatılmaya tepkisiz kalmasından $\mathrm{mI}$, yoksa annesinin ölümüne tepkisizliğinden dolayı $\mathrm{mı}$ yargılandığı belirsizdir. Ancak kayıtsızlık o kadar abartılmıştır ki, "normal bir insan"ın sınırları aşılmış durumdadır.

\section{5. İtiraf (2001)}

Film, mühendis olan Harun ile onu aldatan eşi Nilgün arasındaki tartışmalar ve belirsizlikler üzerine örülüdür. Harun başarılı bir mühendistir ve eşi Nilgün'ün kendisini aldattığına dair şüpheleri vardır. Ancak içinde büyüttüğü bu şüphelere inanmayı ve karısını kaybetmeyi istemediğinden, bu durum ile yüzleşmekten kaçar ve karısına hiçbir şey söylemez. Ancak en sonunda dayanamaz ve karısına her şeyi itiraf ettirmek için onu sorgulamaya başlar. Film, iki kahramanın ilişkilerini ve itiraf sürecini kapsamaktadır. 


\subsubsection{En trajik anında kadından merhamet görmeyen bir erkek, Harun olmak...}

Gerçekliğin toplumsal bağlamda inşa edilmesi yaşamsal bir önem taşımaktadır çünkü toplumsal yapı içerisinde ele alınan ve anlamlandırılan gerçeklik, bu sayede toplumsal bir nitelik kazanır ve bir anlamda yeniden kurulmuş olur.

Yönetmenin ilk filmi olan C Blok’ta evlenerek sınıf atlayan kadın, bu filmde kişisel özelliklerine ve yeteneklerine bakılmaksızın "düzensiz aile yaşamı" yüzünden sınıf düşmüş ve konforlu apartman dairesinden gecekonduda yaşamaya başlamıştır. Nitelikli özellikleri olmasına rağmen Nilgün, ağır şartlar altında çalışan işçi konumuna gelmiştir. Tüm bunlar, filmde, Nilgün'ün yani kadının suçu olarak sunulmaktadır (McCarthy, 2002: 46).

Bunların yanı sıra, yıkılan bir evlilik ve ölen bir koca üzerine kurulan ilişkide "şimdiki geçmiş" ile "olan geçmiş" arasında kadın ve erkek açısından farklı yansımalar vardır. Bunlar, erkeğin kadına olan güvenini sarsarken her iki tarafın da suçluluk duymasına yol açmıştır. Erkek, içindeki kuşku sebebiyle kadın üzerinde baskı oluşturmaya çalışmış, kadın ise kaçış yolu olarak başka bir birlikteliğe yönelmiştir. Dolayısıyla filmde "Şimdiki geçmiş" ile "yaşayan geçmiş" birbirine karışmış durumdadır.

Yönetmen, önceki filmlerinde olduğu gibi burada da toplumun alıştığı kadın ve erkek tanımlarını kırmıştır. Demirkubuz'un kadın karakterlerinde genellikle "cinsel düzensizlik" söz konusudur. Yönetmenin sinemasında "çapkın" erkeklerin yerini bir nevi çapkın kadınlar almıştır. Bu yüzden İtiraf'ta da bu temalar ağırlıklı olarak hissedilmektedir.

Görünürde Harun'a da Nilgün'e de mesafeli yaklaşılmaktadır. Çift arasında Taylan'ın ölümüne ilişkin geçen konuşmalar, her iki tarafın da bu ölümde payının olduğunu sezdirir. Pösteki de her iki tarafın da ölümle ilgili olarak suçu paylaştığını şöyle ifade etmektedir (2005: 96).

Filmde, karakterlerin geldikleri bu noktada erkeklerin payının olup olmadığı sorgulanmalıdır. Neticede Harun, Nilgün ile Taylan evliyken, Nilgün ile beraber olmuş; onunla birlikte olduğu için de içten içe kadını suçlamıştır. Bu yüzden bir gün aynı şeyin kendisinin başına geleceğini düşünerek, endişeli bir ruh hali içindedir. Bunu da Nilgün ile olan tartışmasında gizlememiştir. Tartışma sonrasında Harun'un kadının ayaklarına kapanması, erkeğin iyi niyeti ve sevgisini temsil ederken, kadının bunun üzerine kocasını bırakıp sevgilisine gitmesi ise, adilik ve acımasızlık olarak izleyiciye aksettirilmektedir.

Demirkubuz'un filmlerinde güvenini kaybeden erkek, ya tepkisizleşmekte ya da saldırganlaşmaktadır. Harun'un hayat şekli ve tavırları "normal şartlarda" şiddete başvurmayacak bir erkek imajı vermektedir. Karısının suskunluğu ve aldatıldığını düşünme ihtimali karşısında krize giren Harun'un kadına uyguladığı şiddet, bir nevi sapma olarak nitelendirilebilir. Burada verilmek istenen, erkeğin kadına olan saldırısı veya Nilgün'ün boğazına sarılması değil; kadının erkeğine yaptığı yanlış sonucu, erkeğin sabrının taşmasıdır. 
Filmde, temelde ilgilenilen konu olaylar karşısında erkeğin ne hissettiği ve kendisini nasıl ifade ettiğidir. Erkek yaşantısı, kadın yaşantısının önüne geçmiştir. Kadın, erkeğin trajik anlarında devreye girmekte, buralarda da, erkeğe karşı merhamet etmemektedir. Öte yandan Harun karakteri, hayatındaki kadın karşısında mazlumlaştırılmış, hatta Nilgün'ün eski eșinin bile Nilgün onu Harun'la aldattığı için intihar ettiği öne sürülmek istenmiştir. Dolayısıyla, Demirkubuz'a göre, burada da kadın karakterler, erkekler tarafından bir türlü anlaşılamamaktadır. Harun, trajik bir karakter olarak mazlumlaştırılırken, bir bakıma çocukluğa hapsedilmektedir. "Yeter ki ne yaşadığımı bileyim" diyen Harun, kadın karşısında korunmasızdır. Filmin ilerleyen sahnelerinde Harun'un kendisini temize çıkarmak istemesi de söz konusudur. Taylan'ın ailesiyle görüşüp, her şeyi anlatan Harun, adeta günah çıkarmak isteyen bir erkek olarak izleyici karşısındadır. Taylan'ın annesi anlatılanları dinledikten sonra Harun'u kovar. Harun, yaptığı bu itiraftan sonra intihara kalkışır, ancak ölmez.

Nilgün ise özel hayatındaki çalkantılar, patronunun kulağına gittiği için işten ayrılmak zorunda kalır. Burada, kadının özel yaşamı ile iş hayatı birbirine bağlanmıştır. Nilgün'ün beraber aşk yaşadığı diğer adam, filmde gözükmez. Bu adam da, evli ve iki çocuklu olduğu için, Nilgün karakterini "yuva yıkan" konumuna yerleştirmiştir. Ayrıca yaşananları öğrenen adamın on iki yaşındaki kızının babasına ağır bir mektup yazıp intihar etmesi de, Nilgün'ün küçük bir kızın ölümünden sorumlu tutulmasına neden olmuştur. Nilgün'ün sevgilisi, tüm bu yaşananlardan sonra karısına döner. Nilgün ise, erkeklere yaşattıklarının cezasını çekercesine, bir gecekondu mahallesine yerleşmiştir. Üstelik hamiledir ve ne yapacağını bilememektedir. Sonuçta, kadın yine bu filmde de, suçlu, günahkâr, çaresiz ve güçsüz konumda temsil edilmiş olmaktadır.

\subsection{Bekleme Odası (2003)}

Suç ve Ceza'yı çekmeye çalışan Ahmet (Ahmet rolünü ironik biçimde Zeki Demirkubuz canlandırmaktadır), asistanı ile beraber Raskolnikov karakteri için yeni bir oyuncu bulma arayışına girer. Bu süreçte, Ahmet'in sevgilisi Serap, Ahmet’in hayatında başka bir kadının olduğunu düşünerek onu terk eder. Hayata karşı iyice kayıtsızlaşan Ahmet ise, Raskolnikov karakteri için en uygun kişinin evine giren hırsız olduğuna karar verir ve olaylar gelişir.

\subsubsection{Bir yönetmenin yalan! dünyası}

Ahmet, insani değerlere inancı olmamakla beraber, yaşamla bağını tensel hazlar üzerinden kurmayı denemektedir. Hayatındaki kadınların tümü ona kedileri gelmekte olup kadınları hayatına almak için herhangi bir çaba sarf etmemekte ve ilişkilerinde duygusal bağ kurmamaktadır

Bu filmde, Yazgı'da olduğu gibi, bir yuva sıcaklığından eser taşımayan 'bekâr evi' vardır. Evdeki tek sıcaklık kaynağı, salonun ortasında yer alan televizyondur. Televizyon, izleyiciyi sanal gerçeklik içerisine hapsederek, onlara sunduğu hikayeler ve gerçeklik algısı ile zaman ve mekân bağlarının zayıflamasını sağlamaktadır. Ahmet de yabancılaşmışlık duygusu ile yüzleşmekten kaçabilmek için televizyonu bir araç olarak kullanmaktadır.

Ahmet, içinde bulunduğu tekinsiz ve tuhaf davranışları ile anlaşılması zor bir insan 
figürü çizmektedir. Kendisi için çizdiği bu karakter aracılığıyla kendisine "kötü" bir şöhret yaratmaya çalışarak aslında bir tür bilinirlik oluşturmak istemektedir. Hatta evine soygun için giren hırsıza filminde başrol teklif etmesi, kendisi için oluşturmaya çalıştığı imajın bir göstergesidir. Hırsızı suçüstü yakalayıp, daha sonrasında karakolda onu ifşa etmemesi hatta kendisine filminde başrol teklif edişi üzerine, Ferit onun polis olduğunu düşünerek "Ne biçim yönetmensin abi sen ya?" der. Ahmet'in "Nasıl oluyormuş yönetmen? Var mı bildiğin bir yönetmen?" diye sorması üzerine, genç şöyle cevap verir: "Var, Sinan Çetin var... Aslan gibi adam, yönetmen diye ben ona derim işte..." Ahmet ana akım medyada boy gösterebilecek kadar popülerlik sahibi bir yönetmen olmadığı gibi kendisi ile ilgili bir reklam çalışması yapmaya da gerek duymamaktadır. Zira Ahmet daha ziyade kült bir yönetmen olma arzusundadır.

Ahmet, yaşadıkları ve seçtiği hayat içerisinde ele alındığında, alışılagelmiş yönetmen kalıplarının dışındadır. Ahmet'in hayranlarının olma intimalini değerlendirmesi onun tanınma intimaline dair bir tutku içinde olduğunun göstergesidir.

Toplumsal gerçekçilik çerçevesinde bakıldığında Ahmet'in henüz ses getirmiş bir filme imza atamamış oluşu, kendisi için yaratmaya çalıştığı karakteri oluşturabilmesine engeldir. Aynı zamanda Ahmet karakteri ile anlatılan sinema dünyası, izleyiciye film yapım süreci ve bu süreç içerisinde kamera arkasında yaşanan zorlukları da göstermektedir. Filmdeki Ahmet karakteri üzerinden toplumun yönetmenden beklediği davranış biçimleri eleştirilmekte ve kalıplaşmış algılara da bir gönderme yapılmaktadır. $\mathrm{Bu}$ filmde yine birey üzerinden topluma yapılan bir eleştiri ve farklı bir bakış açısı sunma amacı olduğunu söylemek mümkündür.

"Bekleme Odası"nda yer verilen kayıtsızlık duygusu sözlü dil yerine kamera ve mizansenler aracılığı ile izleyiciye aktarılmıştır.

Filmdeki ana kadın karakterler Serap ve Elif'tir. Elif, geleneksel, tutucu değerlere sahip, mütevazı biriyken sinema sektörüne girince, özellikle de Ahmet'le tanışınca daha farklı davranmaya başlamıştır. Ahmet'le birlikte olduktan sonra bile ona hala "Siz" diye hitap etmeye devam edecek kadar da saygılıdır. Kafası karışıktır ve duygusal biridir.

Serap ise, Ahmet'e göre daha hayat dolu ve hareketlidir. İlişkisini kurtarmaya çalışmaktadır. Ahmet’ten ayrılınca intihar girişiminde bulunur. Ahmet'in tüm kabalığına rağmen ona hep nazik davranmaya çalışır.

Bu filmde de kadınların ruhsal yapısının hep erkeklerin bakış açısından ele alındığı görülmektedir. Başka bir deyişle bu filmin merkezinde de erkek vardır; kadınlar ise erkeğin bulunduğu konuma göre şekillenmektedir. Ahmet'e çay getirip götürürler, o istediğinde Ahmet ile birlikte olurlar. Bu durum, bir anlamda erkek fantezisinin bir ürünüdür. Erkek varoluşsal sorunlara dalıp gitmişken, kadınlar erkeğin intiyaçlarını gidermekle yükümlü kılınmıştır.

Bekleme Odası'nda erkek acısı yine yüceltilmiş, kadını ise bu acıdan arta kalan zamanlara yerleştirilmiştir. Filmde erkeğin sanatsal üretim süreci ve bunun gereği olarak içinde bulunduğu bencillik işlenmiş, kadınların bu koşullara rağmen erkeğin etrafında hazır bir şekilde beklediği ortaya konmuştur. 
Ayrıca Bekleme Odası'nın ana karakteri olan Ahmet'in senaryo yazım süreci ve kadınlarla olan ilişkisinde bir kısır döngüde olduğunu ancak bu tek düzelik içerisinde herhangi bir şekilde değişkenlik yaratmaya çalışmadığı görülmektedir. Filmde hayatından bir kesit sunulan Ahmet, kurduğu ilişkilerde yeterince içten değildir ve kadın karakterlerin figüranlığa indirgendiği bir film üzerine çalışmaktadır. Filmde, Ahmet dışındaki diğer kahramanlar gerçeklik değerini taşımaktadır. Onlar ilişkilerinde oldukları gibi görünmekte, Ahmet ise çevresindekilere karşı yalan değerini ortaya koymaktadır. Ahmet dış dünyaya kayıtsız olduğu için gerçeklerden kaçmakta, kendisine kurgusal bir yaşam kurmaktadır. Filmin final sahnesi ise Ahmet'in bu şekilde yaşamaya devam edeceğinin işareti olmaktadır.

\subsection{Kader (2006)}

Ana hatları ile Kader, yönetmenin önceki filmlerinden Masumiyet'in devamı niteliğindedir. Masumiyet’teki Bekir ve Uğur'un hikâyelerinin öncesi anlatılmaktadır. Babasının sahip olduğu bir mobilya dükkânını işleten Bekir, dükkânına gelen Uğur'a ilk görüşte âşık olur, onunla birlikte olmak için işini, ailesini bırakıp peşinden yollara düşer. Bekir gibi imkânsız bir aşkla bir başkasını seven Uğur da sevgilisinin peşinden şehir şehir dolaşır. Kader, birbirini hiç bırakmayan üçlü bir aşk hikâyesini konu edinmektedir.

\subsubsection{Erkeğin dünyasında Uğur olmak...}

Toplumda kadın ve erkeğe ilişkin ortaya konulan ikiyüzlü namus anlayışına dayanan fuhuş olgusunun kaçınılmazlığının meşrulaştırılmasında kullanılan en önemli mitlerden biri, erkeğin ve kadının doğalarının farklılığı dolayısıyla erkeğin dizginlenemez cinsel dürtülerinin fuhuşun kurumsallaştırılmasını zorunlu kıldığıdır (Roberts'tan akt. Açıkalın, 2008: 12). Aynı zamanda erkek için bir eğlence aracı olan fuhuş, "namuslu" kadınlar ile yaşayamayacakları istek ve duygularını bastırmak için de aracı bir kurum olarak görülmektedir.

Toplumsal gerçekçilik açısından değerlendirildiğinde, Demirkubuz sinemasında kadınlar geleneksel roller içinde temsil edilmemiştir. Erkekler de hegemonik erkeklikten yer yer uzaklaşmıştır. Ancak öyküler, kadınların ikincilleştirilerek değersizleştirilmesi karşısında yeterli direnci gösterememiştir. "Femme fatale" tiplemelerine yakınlaşan kadınlar yarattıkları tekinsizlik ile erkek yaşamlarını tehdit etmiş ve erkekleri felaketlerine sürüklemiştir. Yönetmen bu filmde bireyin toplumsal normlar çerçevesinde sıkışıp kalmışlığı ve buna karşı sergilenen tavrın bireyi içine düşürdüğü yalnızlık ve ötekileştirilme durumu ile izleyiciyi yüzleştirmektedir. Toplumsal normlar ve toplumda kabul gören genel ahlak anlayışı dışında tavır sergileyen bireyin dışarıda bırakılması ve hayatının alt üst oluşu üzerinden yapılan bir eleştiri söz konusudur. Bu filmde de Demirkubuz içe dönük, üstü örtük toplum gözlemleri yapan sinema anlayışını sürdürmektedir (Pösteki, 2005: 254-255). Bir nevi, toplumda üstü kapalı kalmış ya da gözler önünde yaşanmayan olayları anlatmaktadır. Kader filmi için, Sabri Büyükdüvenci, "Zeki Demirkubuz Masumiyet ve Kader’le klasik Yeşilçam melodramlarını dönüştürmektedir" ifadesini kullanmıştır (2007: 46).

Filmde Bekir karakteri, kontrol edemediği bir kadını sevmektedir. Bekir, aslında arzuladığı şeye (Uğur) ulaşmak istemekte; arzusunu evcilleştirebileceği koşulları 
yaratmaya çalışmakta ancak başarılı olamamaktadır. Kader'de de erkek arzusu bir türlü tatmin edilemez ve erkeğin yaşamı, bir kadına âşık olunca alt üst olur. Oğuz Ayaz, burada Uğur ve Bekir'in kader tutsağı olmadıklarını, arzularının peşinden gittiklerini belirtirken (2007: 13) Demirkubuz karakterlerin kendi arzularının ve tutkularının peşinden koşmalarını aslında kaderin ta kendisi kabul etmektedir.

Demirkubuz'un sinemasında genellikle aile içi düzen sürekli olarak bozulmakta ve yönetmen bu bozulmadan genellikle kadınları sorumlu tutmaktadır.

Filmde, Uğur karakterinin bedeninin parça parça gösterilmesi, kadının bedeninin farklı bölgelerine odaklanılmasına sebep olmuştur. Bu odaklanma bazen kameranın konumlandırılışı bazen de Uğur'un giydiği kıyafetler ile gerçekleşmektedir.

Uğur karakteri, haylaz, şımarık, fazlası ile açık sözlü, alaycı bir kadındır ve Zagor’a aşıktır. Bir bakıma Uğur sürekli olarak suç işlemeye devam eden Zagor'a adanmış bir hayat yaşamaktadır. Hatta öyle ki Zagor için fahişelik yapmaya dahi başlamıştır. Uğur için Zagor ile olan ilişkisinden daha önemli bir şey yoktur. Uğur'un Zagor'u bu kadar yüceltmesinin nedeni belki de bir türlü ona kavuşamıyor oluşudur. Masumiyet filminin devamı niteliğinde olan bu filmde, yine Masumiyet'te olduğu gibi kadınlar için iki seçenek vardır: Kendilerinden beklenen klasik rolleri yerine getirmek ya da "fahişelik" ile güçlenmek.

Bekir için genç kadının, kendisinden aldığı borç parayı ödemek üzere "fahişelik" yapacak olması, metresliği kabullenmesi Zagor'u ne kadar sevdiğinin göstergesidir. Kadına iş hayatında "fahişelik", "metreslik", "taşra gazino şarkıcılığı" layık görülmüş, diğer tüm yollar kapatılmıştır. Öte yandan Bekir'in annesi ve karısı "boyun eğen", "kaderine razı gelen" karakterler olarak çizilmiş olup ve "iyi eş", "iyi anne" kriterlerini yerine getirmektedirler. Ön plana çıkarılmış kadınlığın sınırlarının dışına taşan Uğur ise, ne "iyi bir eş" ne de "iyi bir anne"dir. Uğur'un bütün hayatı boyunca "fahişelik" yapmayı göze alması, sadece kapitalist sistemin suçu değildir; bunda erkek egemen toplumun ve erkek egemen düşünce biçiminin de payı büyüktür.

\subsection{Kıskanmak (2009)}

Nahit Sıtkı Örik'in "Kıskanmak" isimli romanından sinemaya uyarlanan film 1930'lu yıllarda Zonguldak'ta geçmektedir. Olaylar dizisi anne ve babasını kaybetmiş iki kardeş olan Seniha ve Halit üzerinden gelişmektedir. Her iki kardeş de kırklı yaşlardadır. Halit, Mükerrem ile evlidir. Üçü birlikte, İstanbul'da yaşarken bir iş dolayısı ile Zonguldak'a gitmek durumunda kalırlar. Seniha, gelinleri Mükerrem'in güzelliğini, gençliğini ve çekiciliğini çok kıskanmakta ve onunla iyi geçinir gibi görünse de Mükerrem'i zor duruma düşürmek için uğraşmaktadır. Mükerrem ise, eşi kendisinde yaşça çok büyük olduğu için, mutsuzdur. Birgün, Cumhuriyet Balosu'nda yakışıkı bir genç olan Nüzhet ile tanışır ve ardından aralarında bir ilişki başlar. Bu birlikteliği öğrenen Seniha, durumu ağabeyine anlatınca, dört kişinin de hayatı bir gecede değişmiş olur. 


\subsubsection{Cirkin bir kadının trajedisi ya da kadın, kadının kurdudur...}

Filmde bir kadının, ağabeyine duyduğu öfke nedeni ile, diğer kadınlara zarar verme çabası görülmektedir. Ana karakter intikam alabilmek için etrafındaki insanların zaaflarını kullanmaktadır. Demirkubuz bu filminde erkek jargonunu bir kadın üzerinden izleyicisi ile buluşturmuştur. Bu bağlamda bakıldığında, alt metinde yine erkeksi bir tavır olduğu anlaşılmaktadır. Karakterlerin iç dünyaları, ihanet temasının sürekliliği, kadınların "posta koyması", erkeklere direnen bir çıkış yapan ve onlara karşı durabilen kadın portrelerinin işlenmesi, bu durumu olağan bir şekilde sunmayı amaçlamaktadır. Bu da tematik bağlamda bir sürekliliği göstermektedir.

Halit, parayı kazanan ve evin geçimini sağlayan, malın mülkün sahibi, kadınların toplumsallaşmasında ve ailenin toplumsal ilişkilerini belirlemede etkili figürdür. Halit'in toplumdaki statüsü, eşinin ve kardeşinin toplumdaki yerini de belirlemektedir. Bu açıdan yönetmen, erkek egemen bir toplum gerçeğini, geçmiş dönemde ait izlerden yararlanarak, izleyiciye sunmaktadır. Öte yandan filmdeki kadın karakterlere, yönetmen, diğer filmlerinde de olduğu gibi, "utanma", "namus", "kirletilmek" gibi kodlar yüklemiş̧tir. Kendisini sınırlamayan kadın, erkek için fantezilerini gerçekleştirdiği ancak saygı duymadığı bir objeye dönüştürülmekte ve aşağılanmaktadır.

Hem romanda, hem de filmde sorgulanması gereken konulardan biri şu olmalıdır: Seniha'nın içerisinde bulunduğu bu ruh hali ve etrafına zarar vermesinin nedeni çirkin oluşu mu yoksa kendisini çirkin bulması mıdır? Seniha aslında kendisini aşağılayan bir tavra sahiptir. Sürekli kendisinin sevilmeyen, ötekileştirilmiş ve hiçbir şekilde ilgi görmeyen biri olarak ifade etmektedir. Bunun nedeni ise çocukluğunda annesi ve ailesi ile olan ilişkisindeki sorunlarda ve iletişim kopukluğunda gizlidir. Bir yandan kendini çirkin bulup sevilmeye lâyık olmadığını düşünürken, diğer yandan da insanlara acı çektirip onları değersizleștirmesi, insanlarla arasına mesafe koyması, Seniha'nın sınır kişilik örgütlenmesi altında narsisist kişilik sergilediğine işaret etmektedir. Kıskanmak filminde narsist kişilik özellikleri sergileyen bir diğer karakter de aslında Nüzhet'tir. Nüzhet'in kendi güzelliğine hayran ve sağlığına aşırı düşkün olması onun narsist kişiliğe sahip olduğunun en belirgin kanıtlarındandır. (Soylu, 2001: 52-54)

Bir söyleşisinde "insan ilişkilerindeki trajik yönü en iyi aldatma durumuyla ortaya çıkarabildiğini” söyleyen Demirkubuz (Öztürk, 2006: 126), bir başka söyleşisinde de Kıskanmak filmiyle çirkin bir kadının trajedisini anlatmaya çalıştığını ifade etmiştir. (Aytaç, 2009). Aslında kadının yaşadığı trajedinin altında geçmişte yapılan hatalar yer almaktadır. Ataerkil toplum yapısında erkek evlat ailenin geleceği ve soyun devamını sağlayacak birey olduğundan, önceliğe sahip kabul edilir. Bu doğrultuda ailesi, Halit’i eğitimi için Avrupa'ya göndermiş ve kız kardeşi Seniha'nın tüm gereksinimlerini göz ardı etmiştir. Böylece Seniha ailenin erkeklerine bağımlı ve muhtaç duruma düşmüş, ailenin reisi babası ve annesi ölünce, Halit ailenin reisi görevini üstlenmiş ve kardeşinin sorumluğunu alarak onun yaşamını ve cinselliğini kontrol gücünü elde etmiştir.

Zamanla Seniha, Halit'i, onun evliliğini, "güzel" karsını sürekli kıskanır olmuştur. Mükerrem'in yaşadığı yasak aşkı ağabeyi Halit'e anlatıp, sonrasında ağabeyinin Nüzhet'i öldürmesi sonucu hapse girmesi, içten içte Seniha'ya haz vermiştir. Kıskançlık duyguları ile etrafına zarar vermek için çabalayan Seniha'nın, kendisine yapışmış 
olan çirkinlik algısını yıkmak yerine bunu daha çok ön plana çıkarmaya çalıştığı anlaşılmaktadır. Seniha sürekli olarak koyu renk kıyafetler seçmekte ve vücudunu kıyafetleri ile saklamaya çalışmaktadır. Donuk cildi ve kambur duruşu aslında Seniha'ya biraz da güç vermektedir. Sert ve net tavırlar sergilemekte, etrafındaki insanları eleştirmekten hatta onları iğnelemekten çekinmeyen tavırları ile kendisini yok sayan insanları tedirgin etmektedir.

“Kıskanmak" romanının 2008 yılındaki baskısı için önsöz yazan Enis Batur, Seniha'nın aykırı bir femme fatale örneği olarak algılanabileceğini dile getirmekte, Kıskanmak'ta "gerçek kutupların saklandığını, okurun femme fatale konusunda da böylesi bir ters çevirmeyle kuşatıldığını" öne sürmektedir: "Illk bakışta bir homme fatale vardır ortada: Nüzhet. Ancak bütün akışı denetleyen tek kişinin Seniha olduğu, romanın sonunda kavranır" (Batur, 2008: 11).

\subsection{Yeraltı (2012)}

Demirkubuz, bu filminde Dostoyevski'nin Yeraltından Notlar adlı eserinden esinlenmiştir. Filmin hikâyesi Muharrem ana karakteri ekseninde gelişmektedir. Muharrem eskiye dayanan arkadaş grubundan Cevat'ın yazdığı romanın ödül almasını hazmedemez. Arkadaşları tarafından başlangıçta davet edilmediği kutlama yemeğine, çeşitli oyunlarla kendisinin de çağrılmasını sağlar. Amacı fikir hırsızı olduğuna inandığı arkadaşının yüzüne onun ile ilgili fikirlerini söylemektir.

Kent insanının yalınızığı ve amaçsızlığının belirgin olarak anlatıldığı film, Muharrem'in yalnızlığı ile kendini sorgulaması üzerine kuruludur. Film günümüz insanının biraz doğasından biraz da toplumsal koşullardan kaynaklanan "çıkarcılığını" yalın bir şekilde seyirciye aktarmakta ve gerçeği seyircinin yüzüne vurmaktadır.

\subsection{1. “iyi olmak istiyorum ama bırakmıyorlar” tavrı ile Muharrem olmak...}

Filmin ana karakteri Muharrem, bir devlet dairesinde memur olarak çalışan toplumun orta sınıfına mensup bir erkektir. Bir zamanlar yazar olmak için denemelerde bulunmuş ama sonradan bu çabasını bir kenara bırakarak memur olmakta karar kılmıştır. İş yaşamında başarıı ve hırsı biri olmadığı gibi, hayatında da memnun olmadığı şeyleri değiştirecek cesarete sahip değildir.

Yazarlık döneminde ekonomik sıkıntı çekmesine rağmen şimdi en azından belli ve düzenli bir gelire sahiptir. Toplumdaki tabirle "sanatın karın doyurmaması" gerçeğini, Muharrem, yazar olmaktan vazgeçip düzenli bir işe girerek göstermiştir. İşini sevmediği halde kendi deyişiyle "ekmek parası için" katlanmaktadır. Muharrem yalnız yaşadığından ev ya da aile içinde herhangi bir kişiye karşı sorumluluk taşımaz. Toplumun ve kültürün erkek kimliğine yüklediği ve bu erkek kimliğinden beklediği evin reisi koca veya erkek evladın sahip olması gereken değerlere karşı bir yükümlülüğü yoktur.

Toplumsal gerçekçilik çerçevesinden bakıldığında, geleneksel aile yapılarında anne ve babalar, çocuk sahibi olmayı geleceğinin bir garantisi ve yaşlandığında kendilerine bakmaları, ya da hayatı paylaşmak için istemektedirler. Oysa Muharrem, geleneksel 
değerlerin dışında yalnız olmayı seçmiş, gerçek anlamda yalnız bir kişidir. Onun bu kadar yalnız olması, toplumdaki gerçeklikle kısmen örtüşmektedir. Muharrem'in yalnızlığına dikkatli bakıldığında kendi etik değerlerine sahip çıktığı için yalnızlaştığı fark edilmektedir. Riyakârlık, yalancılık, hırsızlık gibi olumsuz özelliklere sahip kişilerden uzak durmayı yeğleyip yalnızlığı tercih etmiştir. Bu sebeple de toplum içi iletişimi zayıftır ve işyerindeki mesai arkadaşlarıyla bile iletişime girmemekte, hatta onlardan nefret etmektedir.

Muharrem, toplumsal yapının erkek kimliğine giydirdiği “olması ve olmaması" gerektiğine dair kodların dışında farklı bir erkek görünümü sergilemektedir. Hayattan memnun değildir. Her şeyden nefret eder. İçinde yaşadığı toplumsal yapının beklentilerine karşılık veremediği için uyum sorunu yaşamakta ve toplum dışı kalmaktadır. Çünkü o insanların duymak istediklerini değil, gerçekleri açık ve dürüst olarak dile getirir.

Toplumsal gerçekçilik anlamında, Muharrem kültürel birikimi olan, sosyo-ekonomik açıdan toplumun orta sınıfına ait, yaşamda kimseye karşı sorumluluğu olmayan, hayatla, toplumsal yaşamla ve insanlarla sorunları olan, içi nefret dolu, yalnız ve kötü bir erkek kimliği çizmektedir. Toplumsal yapının erkeklerden olmasını beklediği güçlü, cesur, kararlı, başarılı, hırslı, etkin gibi özellikleri taşıyan bir erkek kimliğini yansıtmamaktadır.

Film, yemek sahnesi öncesi ve sonrası olarak ikiye ayrılabilir. Yemek sahnesine kadar olan kısımda Muharrem'in büyük şehirde yaşadığı yalnızıık anlatılmıştır. Tek başına ve amaçsız bir şekilde sokaklarda dolaşması, para karşılığında kadınlarla birlikte olması onun yalnızı̆ğının açık bir göstergesidir.

Filmdeki yemek sahnesi ve sonrasında gelen kısımda yalnızlığının onu ne hale soktuğunu ele almak gerekir. Burada geçen diyaloglar ile yönetmen tarafından ben ve biz kavramları sorgulanmaktadır.

Muharrem, karşısında "biz" olarak yer alan Cevat ve arkadaşlarına karşı "ben" olarak durmaya çalışsa da, o topluluğa karşı yenilgiyi kabullenmek durumunda kaldığı için, bundan utanmaktadır.

Ana karakter Muharrem'in mutsuzluğunun ve yalnızlığının temelinde uyumsuzluğu yatmaktadır. Bu uyumsuzluk onun kendisinden beklenenleri yerine getirmemesinden kaynaklansa da, onun beklentileri yerine getirmesine de engeldir. Çünkü bu kişiliğinden vazgeçmesi anlamına gelir. $O$ ise kişiliğinden vazgeçmeyi, başka türlü davranmayı gururuna yediremez, zaten belki istese de yapamaz. Çünkü Muharrem kendisini bu noktaya getiren -ve filmde gösterilen zamandan önce başlamış olan- sürecin sonunda nefret dolu, giderek bu halinden zevk alan ve bunun gururunu yaşayan adama dönüşmüştür. (Ekuklu, 2012: 97)

Muharrem iç dünyasında yaşadığı gel-gitlerden ve yaşadığı duygusal yıkımdan sıyrılamayacağını fark ettiğinde, kendisine mecbur olduğu gerçeği ile yüzleşerek etrafındaki eşyaları ve evini kırıp dökmeye başlar. 
Filmin ana metnini ve anlatmak istediğini aslında Muharrem'in “ijyi olmak istiyorum ama bırakmıyorlar" cümlesinden çıkarılması mümkün olabilecektir.

\subsection{Bulantı (2015)}

Filmde, eşini ve çocuğunu kaybetmiş olan "entel" bir adamın, başına gelen tüm "trajik" olayları umursamadan hayatına devam etmesi ve sonrasında sıkıntı yaşaması anlatılmaktadır. Yönetmen, 2003 yapımı Bekleme Odası'nda olduğu gibi bu filmde de ana karakteri canlandırmaktadır.

\subsubsection{Bir vicdan muhasebesi, Ahmet olmak...}

Filmde, Ahmet karakterinin bunalımı sinemada alışkın olunanın aksine nedensonuç ilişkisi içinde anlatılmamakta, bu da seyircinin filmden kopuk kalmasına sebep olmaktadır. Filmde final sahnesi dışında neden-sonuç ilişkisi son derece zayıf görülmektedir.

Bulantı'da yönetmen iyi ve kötü kavramlarını vurgulamayı hedeflemiștir. Toplumsal kurallar ve bunların beraberinde getirdiği baskı sonucu kabullenilen doğru ve yanlış algısını izleyiciye aktarmak yerine bireyin ve toplumun kalıplaşmış yargılarının dışında davranışlar izleyiciye sunulmuştur. Bu nedenle Ahmet eşini ve çocuklarını kaybeden bir adamın toplumun kendisinden beklediği matemi yaşaması yerine bu olaya duyarsız kalan ve etrafına karşı yardımsever tavırlar sergileyen bir karakter olarak belirmektedir. Bu çelişkili tablo Aslı'nın Ahmet'e yönelttiği "Hem nasıl bu kadar korkak, hem nasıl bu kadar acımasız olabiliyorsun? Ahmet, sen karısını çocuğunu kaybetmiş bir adamsın. Ama şu halimize bir bak. Karısını çocuğunu kaybeden ben, hiçbir şey olmamış gibi davranan sensin sanki." sözleriyle vurgulanmaktadır.

Ahmet kendisinden yaşça küçük bir kadın ile yaşadığı birlikteliği ve sergilediği vurdumduymaz hareketleri ile toplumun onayının dışında hareket etmektedir. İçinde bulunduğu yalnızlıkta kaybolan Ahmet, filmin finalinde ise binanın bodrum katında yaşayan ve kendisine temizlikçi olarak yardıma gelen Neriman'ın dizinde ağlar. Bu aslındaAhmet'in vicdanını temizlemek için sergilediği bir davranıştır. Filmde karakterlerin içten içe kötülüğe yakın duruşlar sergilemesi, olaylar karşısında vurdumduymaz tavırlar göstermeleri ve içten içe savaş verdikleri vicdanları önemli detaylardır. Sevgilisiyle olduğu gece, hem karısını, hem de çocuğunun ölüm haberini alan Ahmet’in kayıtsızlığı bir süre sonra vicdan muhasebesi yapmasına sebep olacaktır.

Demirkubuz'un diğer filmlerinin sonunda, kişilerin kayıtsızlığı, ilgisizliği, isyanı veya öfkesi yansıtılırken, bu filmde, biraz daha farklı olarak, karakterin vicdanıyla yüzleşmesi, temizlikçi kadının ayaklarına kapanarak, kendisini sorgulaması şeklinde verilmiştir. Saflıkla yüzleşen ve nihayetinde bir arınmaya dönüşen "Bulantı" için, bir tür duygu ve kibir ezilmesi değerlendirmesi yapmak mümkün görünmektedir. 


\section{Sonuc}

Zeki Demirkubuz toplumsal gerçekçi bir ele alış ile seçtiği kendine has temaları ve temalarına getirdiği sinemasal anlatım biçimiyle ile kendi sinemasını inşa etmiş bir auter yönetmen olarak Yeni Türk Sineması'nın başlıca isimler arasındadır. Toplumsal sorunların üzerinden yola çıkan yönetmen var olan toplumsal gerçekliği tüm inciticiliği ile sunmaktadır. Karakterleri ise toplumsal gerçeklik çerçevesinde oldukça örselenen ve mevcut tablo içinde kendi "çıkış" yollarını arayan figürlerdir. Bu boyut ile yönetmen toplumsal gerçekliğin tanımladığı sorunlar üzerinden bireyin dünyasına gitmekte, ardından söz konusu koșulların "mağduru" olan karakterlerin topluma geri bildirimlerini konu edinmektedir. Dolayısı ile Demirkubuz Sineması toplumsal sorunlardan bireyin dünyasına kendine has bir anlatım biçimi getirmektedir.

Demirkubuz geleneksel anlatı kalıplarını kırarak bireysel hikâyeler üzerinden toplumsal yaşama içkin bir izdüşüm getirmektedir. Toplum gerçekliğini bir tema olarak kadın ve erkek öğeleri üzerinden ișleyen yönetmen ekseriyetle kadının aldatmasını ele alarak, aldatılan erkeğin trajedisini, toplumun farklı bir gerçeği olarak sunmaktadır.

Yönetmenin filmlerinde aile birliği ya hiç yoktur, ya bozulmuştur ya da genellikle kadın karakterlerin aldatmaları sonucu bozulmak üzeredir. Demirkubuz sineması kadının aldatması üzerine kuruludur ve filmdeki erkek karakterlerin kadının aldatma eylemi karşısındaki tepkileri geleneksel değerlerin dışındadır. Zeki Demirkubuz filmlerinde toplumsal ya da varoluşsal bir durumun köşeye sıkıştırdığı bireylerin öyküleri anlatılmaktadır.

Yönetmenin filmlerindeki erkekler, genellikle yaşamlarında yalnız, bencil, asosyal, içine kapanık, hayatın içinde kaybolmuş, hayatla ve kendileri ile sorunları olan, saplantılı, güçsüz kimlikler olarak yansıtılmaktadır. Demirkubuz filmlerinin en önemli özelliklerinden birisi, yönetmenin hikâyelerini (C Blok ve Kıskanmak dışında) erkek karakter üzerine oturtmasıdır. Erkek kimliğine toplum tarafından yüklenen özelliklerden duygularını belli etmeme Demirkubuz'un filmlerinde yıkılmaktadır. Demirkubuz'un erkekleri, duygularını belli etmekten kaçınmamakta ve rahatlıkla ağlayabilmektedir. Buradan hareketle, toplumsal gerçeklikte yaşanan değişim ve dönüşümlerin erkeğin de yaşantısı, hayata bakış açısı, davranış biçimlerini değişmiş olduğu sonucuna varılabilmektedir. Yönetmen, erkeklerin duygu durumunu ve yaşadıkları psikolojik travmayı, toplumdaki değişikliklerden etkilenerek yansıtmıştır. Söz konusu durum 'toplumsal gerçeklik' bağlamında ele alındığında, erkekler ile ilgili çok fazla tartışma konusunun ortaya çıktığı görülmektedir. Demirkubuz filmleri, öncelikle: "Erkekler hep aldatılır mı?", "Aldatıldıkları için mi mutsuzlar?", "Erkeklerin bozuk ruh hallerine sebep sadece onları aldatan kadınlar mıdır?" biçiminde özetlenebilecek soruları üzerine izleyiciyi düşünmeye zorlamaktadır. Tüm bu sorular ile yönetmen izleyicisini toplumun yarattığı ya da yok saydığı karakter ile karşı karşıya getirmektedir. Bu yüzden, başlangıçtaki varsayım, sonuçta doğru çıkmakla birlikte, kendi içinde birtakım sebepler barındırmaktadır. Yani, erkekler, toplumdaki değişik yapıdan ve yozlaşmadan etkilenirler. Ancak, erkeklerin psikolojisini mahveden şey, salt kadınların aldatışına indirgenmemelidir.

Geleneksel erkek kimliğinde önemli olan namus kavramı, Demirkubuz filmlerinde 
önemini yitirmektedir. Bunun en net örneği Demirkubuz'un "Masumiyet" ve "Kader"inde görülmektedir. Anılan tablo, toplum içerisinde var olan ancak bastırılmış ve yok sayılmaya çalışılan bireylerin Demirkubuz Sineması'nda izleyici ile yüzleştirilmek istenmesinin göstergesidir. Yönetmen alışılagelmiş tavrın dışına çıkarak toplumun temel yapı taşını oluşturan bireyin yaşantısı üzerinden hikâyelerini anlatmaktadır. Genellikle tercih edilen anlatım biçimi gündelik hayatta sıklıkla karşılaşılan karakterler üzerinden hikâyelerin oluşturulması iken, Demirkubuz toplumun ötekileştirdiği ya da yok saydığı bireyler ile izleyiciyi karşı karşıya getirerek, bir tür yüzleşmeye kapı aralamaktadır.

Demirkubuz Sineması'nda kadınlar ise, erkekleri aldatan, para veya sınıf atlamak uğruna her türlü yolu mubah görebilen, toplumda çalışarak bir yere gelememiş, hep ikinci planda olan, şiddet gören, ses çıkarmayan, güçsüz, mücadele etmeyen, intiraslarının peşinden koşan, çıkarı için onurunu hiçe sayan özellikler ile karakterize edilmektedir. Filmlerde çoğunlukla erkeğin fantazi nesnesi olarak konumlandırılmış kadın, toplumda genel kabul gören 'kadın' kimliği ile örtüşmemekle beraber, yönetmen tarafından böyle hayatların da olabileceğine dikkat çekmek gayesi ile sunulmaktadır.

Demirkubuz, toplumda var olan ve yok sayılan hayatları bireysel hikâyeler üzerinden oluşturduğu filmleri ile izleyicisine sunmaktadır. Yönetmen önemli ölçüde, ötekileştirilmiş, yalnızlaştırılmış ve yok sayılmış bireysel yaşam öyküleri anlatırken, söz konusu bireysel yaşam öykülerinin toplumsal gerçeklik konusu meselelerin bir sonucu görünümü arz etmesi yönetmenin sinemasının toplumsal gerçekçi arka planını dikkate değer kılmaktadır. Bu yönü ile yönetmen inşa ettiği "dramatik uzayda" toplumsal gerçeklik ve bu gerçekliğin sonuçları bakımından sinemaya taşınmayan konular ele alması nedeniyle de özgün bir değer taşımaktadır.

Yönetmenin, filmlerinde gişe kaygısından ziyade sanatsal bir gaye taşıyor olmasının sinemasında daha özgür bir tutum sergilemesine katkı sağladığı anlaşılmaktadır. Yönetmen bu sayede alışılagelmiş ve beklenen anlatım kalıplarının dışına çıkabilmiştir. Demirkubuz'un karakterleri kimi zaman toplum tarafından kabul görmek için çabalarken kimi zamanda normları reddederek hayallerinin ve tutuklularının peşinden gitmeyi tercih etmektedir. Yönetmen, toplumda genel kabul gören güzellik anlayışı ya da kadının toplumdaki yeri gibi konuların dışında kalabilmiştir.

Zeki Demirkubuz, filmlerinde devamlılığı önemli ölçüde diyaloglar ile sağlamaktadır. Geri planda müzik yoktur. Yönetmenin kurguda devamlılığa önem vermediği, olayları açıklamadığı ve bu doğrultuda çabasının da olmadığı anlaşılmaktadır. Ayrıca, kapıların ve ışıkların kapanıp açılmasıyla yapılan geçişler, sürekli çalışan bir televizyonun olması, yönetmenin filmlerinde kullandığı ortak zamansal ve mekânsal geçişlere örnektir.

Ana hatları Zeki Demirkubuz'un toplumsal gerçekçilik eksenli yapıtlar ortaya koyduğunu ve birey toplum ilişkisini farklı ve çarpıcı hikâyeler ile ele aldığını söylemek mümkündür. Toplumsal gerçekçiliğin salt bugün içinde bulunulan durumu ve toplumsal yapıyı anlatmak olmadığı, var olan sürecin nelere sebep olabileceğini de ifade etmek olduğu düşüncesi temel alınırsa; yönetmenin filmlerinde, mevcut durumun ve olası etkilerinin yansımalarının olduğu da net bir biçimde dile getirilebilmektedir. 


\section{Çözümlenen Filmlerin Künye Bilgileri}

C Blok (1994) Yönetmen: Zeki Demirkubuz, Senaryo: Zeki Demirkubuz, Görüntü Yönetmeni: Ertunç Şenkay, Kurgu: Nevzat Dişiaçık, Oyuncular: Serap Aksoy, Zühal Gencer, Fikret Kuşkan, Selçuk Yöntem, Ülkü Duru, Feridun Koç, Sanat Yönetmeni: Ayşe Akılıoğlu, Yapımcı: Zeki Demirkubuz, Müzik: Serdar Keskin, Süre:87 dakika.

Masumiyet (1997) Yönetmen: Zeki Demirkubuz, Senaryo: Zeki Demirkubuz, Görüntü Yönetmeni: Ali Utku, Kurgu: Mevlüt Koçak, Oyuncular: Derya Alabora, Haluk Bilginer, Güven Kıraç, Melis Tuna, Yalçın Çakmak, Ajlan Aktuğ, Nihal G. Koldaş, Doğan Turan, Sanat Yönetmeni: Burcu Unurtan, Yapımcı: Zeki Demirkubuz, Nihal Koldaş, Müzik: Cengiz Onural, Süre:110 dakika.

Üçüncü Sayfa (1999) Yönetmen: Zeki Demirkubuz, Senaryo: Zeki Demirkubuz, Görüntü Yönetmeni: Ali Utku, Kurgu: Nevzat Dişiaçık, Oyuncular: Ruhi Sarı, Başak Köklükaya, Cengiz Sezici, Serdar Orçin, Emrah Elçiboğa, Naci Taşdöven, Sanat Yönetmeni: Tülin Çetinkol, Yapımcı: Zeki Demirkubuz, Müzik: Cengiz İmren, Süre: 92 dakika.

Yazgı (2001) Yönetmen: Zeki Demirkubuz, Senaryo: Zeki Demirkubuz (Albert Camus'nün aynı adlı romanından), Görüntü Yönetmeni: Ali Aktaş, Kurgu: Zeki Demirkubuz, Oyuncular: Serdar Orçin, Zeynep Tokuş, Engin Günaydın, Demir Karahan, Sanat Yönetmeni: Bahar Evgin, Yapımcı: Zeki Demirkubuz, Müzik: Can Hakgüder, Süre:120 Dakika.

İtiraf (2001) Yönetmen: Zeki Demirkubuz, Senaryo: Zeki Demirkubuz (Albert Camus'nün aynı adlı romanından), Görüntü Yönetmeni: Zeki Demirkubuz, Kurgu: Zeki Demirkubuz, Oyuncular: Taner Birsel, Başak Köklükaya, İskender Altın, Miraç Eronat, Gülgün Kutlu, Abdullah Demirkubuz, Sanat Yönetmeni: Bahar Evgin, Yapımcı: Zeki Demirkubuz, Süre: 90 dakika.

Bekleme Odası (2003) Yönetmen: Zeki Demirkubuz, Senaryo: Zeki Demirkubuz, Görüntü Yönetmeni: Zeki Demirkubuz, Kurgu: Zeki Demirkubuz, Oyuncular: Nurhayat Kavrak, Zeki Demirkubuz, Nilüfer Açıkalın, Serdar Orçin, Ufuk Bayraktar, Eda Teksöz, Güliz PilgeYapımcı: Zeki Demirkubuz, Süre: 92 dakika.

Kader (2006) Yönetmen: Zeki Demirkubuz, Senaryo: Zeki Demirkubuz, Görüntü Yönetmeni: Zeki Demirkubuz, Kurgu: Zeki Demirkubuz, Oyuncular: Ufuk Bayraktar, Vildan Atasever, Engin Akyürek, Müge Ulusoy, Ozan Bilen, Settar Tanrı̈ğen, Erkan Can, Mustafa Uzunyılmaz, Güzin Alkan, Hikmet Demir, Gönül Çalgan, Sanat Yönetmeni: Güneş Çoban, Yapımcı: Mavi Film, Inkas Film, Müzik: Edward Artemiev, Süre:103 dakika.

Kıskanmak (2009) Yönetmen: Zeki Demirkubuz, Senaryo: Zeki Demirkubuz, (Nahid Sırrı Örik'in aynı adlı romanından), Görüntü Yönetmeni: Emre Erkmen, Kurgu: Zeki Demirkubuz, Oyuncular: Nergis Öztürk, Serhat Tutumluer, Berrak Tüzünataç, Bora Cengiz, Hasibe Eren, Nihal Koldaş, Ferdağ Işı, Mustafa Uzunyılmaz, Reyhan İlhan, Serdar Orçin, Rafi Emeksiz, Birsen Dürülü, Yeşim Gül, Şule Demirel, Can Anamur, Hatice Aslan, Sanat Yönetmeni: Nilüfer Çamur, Yapımcı: Zafer Çelik, Zeki Demirkubuz, Müzik: Tamer Çıray, Süre: 96 dakika.

Yeraltı (2012) Yönetmen: Zeki Demirkubuz, Senaryo: Zeki Demirkubuz, Görüntü Yönetmeni: Türksoy Gölebeyi, Kurgu: Zeki Demirkubuz, Oyuncular: Engin Günaydın, Nergis Öztürk, Serhat Tutumluer, Nihal Yalçın, Murat Cemcir, Feridun Koç, Serkan 
Keskin, Sarp Apak, Yapımcı: Zeki Demirkubuz, Süre: 107 dakika.

Bulantı (2015) Yönetmen:Zeki Demirkubuz, Senaryo: Zeki Demirkubuz, Görüntü Yönetmeni: Türksoy Gölebeyi, Kurgu: Zeki Demirkubuz, Oyuncular: Zeki Demirkubuz, Şebnem Hassanisoughi, Öykü Karayel, Çağlar Çorumlu, Cemre Ebuzziya, Ercan Kesal, Nurhayat Demirkubuz, Kaan Turgut, İpek Türktan Kaynak, Mert Salih Öztürk, Bahar Özus, Yazgı Demirkubuz, Aydın Yıldız, Sanat Yönetmeni: Bahar Evgin, Yapımcı: Başak Emre, Ahmet Boyacıoğlu, Süre: 116 dakika.

\section{Kaynakça}

Açıkalın, Neriman (2008). "Toplumda Fahişelik Kurumunun Vazgeçilmezliği Üzerine Mitler: Mersin Örneği”. Uluslararası Sosyal Araştırmalar Dergisi. 1(4): 11-35.

Ayaz, Oğuz (2006). "Yazgı'dan Sonra Kader: Yan anlamları Unutun!". Yeni İnsan Yeni Sinema, Sayı: 18-19: 12-13.

Aytaç, Senem, vd (2009). "Zeki Demirkubuz ile Kıskanmak Üzerine Vaat Edilen ve Mahrum Bırakılan İnsanlar" (Söyleşi). Altyazı Dergisi, 89: 18-22.

Batur, Enis (2009). "Tutkunun Negatif Çehresi Üzerine Kanlı bir Divertimento” (Sunuş yazısı). Kıskanmak. Nahid Sırrı ÖRiK (yazar) İstanbul: Oğlak Yayınları.

Birtek, Güney (2014). "Gerçekliğin ve Samimiyetin Aynasında: Zeki Demirkubuz", http://www. sinematopya.com/2014/08/gercekligin-ve-samimiyetin-aynasinda-zeki-demirkubuz.html, Erişim tarihi: 18.11.2016.

Büyükdüvenci, Sabri ve Öztürk, S. Ruken (2007). "Yeni Türk Sinemasında Estetik Arayışı". Felsefe Dünyası. 2007/2. 46: 45-49.

Camus, Albert (1999) Yabancı, Vedat Günyol (çev.). İstanbul: Can Yayınları.

Coşkun, Esin (2003). Dünya Sinemasında Akımlar. Ankara: Phoenix Yayınları

Çolak, Metin (2011). "Georg Lukacs'ı Yeniden Düşünmek." FLSF (Felsefe ve Sosyal Bilimler Dergisi). Güz (12): 91-124

Daldal, Aslı (2005). 1960 Darbesi ve Türk Sinemasında Toplumsal Gerçekçilik, İstanbul: Homer Kitabevi.

Ekuklu, Bülent (2012). "Yeraltı". Journal of Eurasian Studies, Nisan-Haziran, 4 (2): 96-99.

Gürkan, Hasan (2013). "Orhan Kemal'in Eserlerinde Metropol Yaşam İçerisinde Modern Yaşam Manipülasyonları ve Bireylerin 'Özgür'lükleri'. SDÜ Fen Edebiyat Fakültesi Sosyal Bilimler Dergisi. 29: 219-234.

Hakan, Fikret (2014). Türk Sinema Tarihi. Nigar Pösteki (der.). İstanbul: İnkılap Yay.

Hauser, Arnold (2006). Sanatın toplumsal Tarihi Cilt/2. Yıldız Gölönü (çev.). Ankara: Deniz Kitabevi.

Hayward, Susan (2012). Sinemanın Temel Kavramları. Uğur Kutay ve Metin Çavuş (çev). İstanbul: Es Yayınları.

Jacobson, Roman (1990). Sekiz Yazı. Mehmet Rifat ve Sema Rifat (çev.). İstanbul: Düzlem Yayınları.

Kıraç, Rıza (1997). "C Blok Üzerine Yönetmenin Sözü”, http://zekidemirkubuz.com/Content. 
aspx?ContentID=43. Erişim tarihi: 01.11.2015.

Kibaroğlu, Buğra (2015). Sinema Sanatında Gerçekçilik ve Biçimcilik. Yayınlanmamış Yüksek Lisans Tezi. Ankara: Hacettepe Üniversitesi Sosyal Bilimler Enstitüsü Felsefe Anabilim Dalı.

Koç, Ayşegül (2004). "Vagina Dentata'lar, Femme Fatale'ler: C Blok, Masumiyet, Üçüncü Sayfa ve İtiraf'ta Kadının Temsili”. Türk Film Araştırmalarında Yeni Yönelimler. Deniz Bayrakdar (der.). İstanbul: Bağlam Yayınları.

Lukacs, Georg (2000). Çağdaş Gerçekçiliğin Anlamı. Cevat Çapan (çev). Beşinci Baskı, İstanbul: Payel Yayınevi.

McCarthy, E. Doyle (2002). Bilgi Kültürü: Yeni Bilgi Sosyolojisi. A. F. Yılmaz (çev.). İstanbul: Çivi Yazıları.

Yergebekov, M. (2003) . Tarkovski Sineması. Yayınlanmamış Yüksek Lisans Tezi. Ankara: Ankara Üniversitesi. Sosyal Bilimler Enstitüsü.

Moller, Olaf (2006). "Türk Yönetmenin Sert ve Edebi Ufkuna Yol Gösteren Işık”. Kader: Zeki Demirkubuz, S. Ruken Öztürk (der.) Ankara: Dost Yayınları.

Monaco, James (2006). Yeni Dalga, Ertan Yılmaz (çev.). İstanbul: Artı Bir Kitap.

Moran, Berna (2000). Edebiyat Kuramları ve Eleştiri, İstanbul: İletişim Yayınları.

Oktan, Ahmet ve Küçükalkan, Yavuz (2013). "Kadının Şeytani Kimyası: Üçüncü Sayfa ve Kıskanmak Filmlerinde Kadın Tipolojileri”. Doğu-Batı Dergisi. 64: 221-237.

Özön, Nijat (1966). "Türk Sinemasına Eleştirel Bir Bakış”. Yeni Sinema. Ekim-Kasım. sayı 3.

Öztürk, S. Ruken (2006). "Zeki Demirkubuz Sineması”, Kader: Zeki Demirkubuz, S. Ruken Öztürk (der.). Ankara: Dost Kitabevi.

Pospelov, Genadiy N. (2014). Edebiyat Bilimi, Yılmaz Onay (çev.). İstanbul: Evrensel Basım Yayın.

Pösteki, Nigar (2005). Türk Sinemasına Yeni Bakış: Yönetmen Sineması. İstanbul: Es Yayınları.

"Robert Bresson Sineması ve Au Hasard Balthazar" (2009). Derindüşünce.org. http://www. derindusunce.org/2009/03/25/robert-bresson-inemasi-ve-au-hasard-balthazar/. Erişim tarihi: 05.10.2015.

Refiğ, Halit (2013). Ulusal Sinema Kavgası. İstanbul: Dergah Yayınları.

Scognamillo, Giovanni (1988). Türk Sinema Tarihi 2. Cilt. 1960-1986. İstanbul: Metis Yayınları.

Soylu, Özge (2001). "Nahid Sırrı Örik, Kıskanmak ve Psikanaliz". Yayınlanmamış Yüksek Lisans Tezi. Ankara: Bilkent Üniversitesi Ekonomi ve Sosyal Bilimler Enstitüsü.

Uçakan, Mesut (2010). Türk Sinemasında İdeoloji. İstanbul: Düşünce Yayınları. 